\title{
TO BE OR NOT TO BE HAPPY? THAT IS THE QUESTION OF CONSUMPTION IN SOCIAL BEHAVIORS
}

\author{
Marcio Mota \\ $\mathrm{PhD}$ in Business \\ State University of Ceara - UECE \\ Getulio Vargas Foundation - Sao Paulo School of Business Administration FGV-EAESP \\ Fortaleza, Ceara - Brazil \\ marcio@marciomota.com \\ Delane Botelho \\ $\mathrm{PhD}$ in Business \\ Getulio Vargas Foundation - Sao Paulo School of Business Administration FGV-EAESP \\ Sao Paulo - Brazil \\ delane.botelho@fgv.br
}

Objective: To examine and evaluate the moderating roles of social behaviors and consumption in happiness.

Method: We carried out a survey with 197 real consumers, and used confirmatory factor analysis and linear regression model, with moderation including the Johnson-Neyman technique, to analyze the data.

Main Results: The outcomes contribute to the previous literature on the positive relationships of frugality, hedonism, and social acceptance with happiness and the negative relationships of materialism, social anxiety, and conspicuousness. More specifically, our three hypotheses imply in one positive (i.e., hedonism moderates the positive relationship between happiness and frugality) and two negative moderations (i.e., social anxiety amplifies the negative relationship between happiness and materialism; and conspicuousness negatively moderates the positive relationship between happiness and social acceptance) which were all supported by the literature and by our empirical research.

Theoretical Contributions: Our paper adds to the literature on happiness, from an emerging country perspective, by clarifying the moderating roles of social anxiety, hedonism, and conspicuousness in the relationship between materialism, frugality, social acceptance, and happiness, which still have inconsistences in the literature.

Relevance: Thus far, there is no research on the simultaneous effects of happiness on consumption and social behaviors. We test the moderating roles of social anxiety, hedonism, and conspicuousness in the relationship between consumption and social behaviors, and happiness.

Managerial Contributions: Firms can ensure that consumers react by different levels of these social behaviors while consuming brands or products may and, at the same time, (1) bring some effort to social bonds to their parties, (2) experience happiness, and (3) attract new customers.

Keywords: Happiness. Hedonism. Social Bonds. Conspicuousness. Frugality. Materialism.

\section{$\underline{\text { How to cite the article }}$}

American Psychological Association (APA)

Mota, M., \& Botelho, D. (2021, July/Sept.). To be or not to be happy? that is the question of consumption in social behaviors. Brazilian Journal of Marketing, 20(3), 461-495. https://doi.org/10.5585/remark.v20i3.18367. 


\section{Introduction}

Happiness has been the objective of life for humans, although a complex subject to study. Most people make decisions every day to reach this universal objective. Ancient Greek philosophy started to understand happiness, but only modern biology, philosophy, and psychology started analyzing the consistencies of such construct. Socrates posed the "how should I live?" question almost 2,500 years ago, and modern philosophers try to answer questions such as "what manner of living does make people happy?" and "what makes us happy?"

Empirical research on happiness in social sciences only began in the 1970s when Easterlin (1974) proposed the Easterlin paradox (i.e., the Paradox of Happiness), which states that although higher income leads to higher happiness across individuals and countries, higher income growth over the years is not associated with higher levels of happiness. For example, countries characterized by relatively high growth rates of GDP per capita have not displayed corresponding increases in happiness.

Happiness is a multidimensional aspect of human life (Bögenhold \& Naz, 2018), that can be explained by hedonic, aspirational, and positional discrepancy mechanisms: i) the hedonic treadmill refers to the idea that happiness or well-being may remain unchanged, despite higher material achievements, because of fast adaptation; ii) the satisfaction treadmill refers to the idea that happiness may not increase jointly with income if aspirations rise simultaneously; and iii) the positional treadmill refers to the idea that utility depends on relative, rather than absolute, consumption level, so happiness may be unaffected by a rise in one's income if the income of others in her reference group also rises (Gui \& Stanca, 2010).

Reviews of happiness research (Sjåstad, 2021) concluded that factors such as income and health are strong predictors of happiness only in their subjective aspects, but social connection stands out as an objective factor affecting happiness. However, there are inconsistent results in the literature that we aim to clarify in this article. First, it makes sense that being socially accepted brings happiness, but laboratory studies that prime social rejection experiences in the respondents have generally failed to evidence a negative relationship between social rejection and self-esteem, a predictor of happiness (Sjåstad, 2021; Blackhart et al., 2009).

Second, the use of conspicuous consumption as an instrument to signal relative status has been demonstrated to strengthen social connection (Hu, Xiang, \& Zhong, 2021), so it could strengthen consumer well-being and happiness. For example, Jaikumar, Singh, and Sarin (2018) 
found that higher levels of conspicuous consumption are associated with increased perceptions of subjective economic well-being (i.e., this effect is even more pronounced among households in the 'bottom of the pyramid'). So conspicuous consumption, such as the purchase of jewelry, could reflect one's social position relative to a reference group, which may increase individual happiness by increasing social status (Wang, Cheng, \& Smyth, 2019). However, Frank (2008) argues that increasing consumption of top incomes has an effect on conspicuous consumption of individuals in the lower positions of the income distribution, such that the inequality has increased their effort to maintain the apparent relative position through conspicuous consumption, decreasing their happiness.

Finally, previous research provides evidence that materialism, characteristic of those who seek happiness from external goals such as money, status, and appearance, may forestall the fulfillment of psychological needs, undermining personal happiness (Wang et al., 2017). Nonetheless, there is conflicting evidence in this direction. For example, when adolescents prioritize materialism as a personal value aligned with their parents' materialistic values, the adolescents report higher subjective well-being, implying that materialism itself does not necessarily lead to unhappiness (see Flurry, Swimberghe, \& Allen 2021 for more examples).

Surprisingly, little is known about the relationship between happiness, consumption, and social behaviors (Jaunky et al., 2020). Our paper adds to the literature on happiness by clarifying those issues from an emerging country perspective. Empirical researchers have begun to state some interesting developments about this issue, and we are on the verge of advancing in substantial aspects. Tanzer and Weyandt (2020) concluded that happiness is better assumed within its behavioral context which can be related to other social behaviors and bonds. Some studies established relationships between happiness and social anxiety (Schroeder \& Dugal, 1995; Mattick \& Clarke, 1998), social acceptance (Schroeder \& Dugal, 1995), and frugality (Lastovicka et al., 1999).

To the best of our knowledge, there is no study yet on the simultaneous effects of happiness on consumption and social behaviors. Indeed, Audette et al. (2018) suggest that scholars of happiness must expand research into determinants that may include other social factors. This topic is still in its infancy and, in line with these authors, we shall need to make progress in empirical and experimental studies by facing this interdisciplinary study of happiness and how consumption and social behaviors are related to each other. The objective of this paper is to examine and evaluate the moderating roles of social behaviors and consumption in happiness. Specifically, we test the moderating roles of social anxiety, 
hedonism, and conspicuousness in the relationship between materialism, social acceptance, and happiness, which still have inconsistences in the literature.

The remainder of this study is organized as follows. We present the first part based on the literature review on happiness, materialism, hedonism, conspicuousness, social anxiety, frugality, and social acceptance. The second part is the method, followed by the results and their discussion. Finally, we provide the final remarks, with implications, limitations, and future research directions.

\section{Conceptual background and hypothesis development}

Social bonds are extremely important for happiness (Diener \& Seligman, 2002) due to the happiest ones have good social connections and spend most of their time socializing and the others who do not establish relationships are considered socially anxious and, consequently, unhappy (Myers, 2000). Social acceptance is also related to bonds the way people are positively or negatively judged by others in social patterns (Baumeister \& Leary, 1995).

In line with this, if one is guided for extrinsic goals, conspicuousness reflects on the status and social position because of the approval of others (Kaus, 2013). Finally, while materialists buy products to be admired by others and to express social relationships and approval (Goldsmith \& Clark, 2012), and hedonism make people more sociable (Veenhoven, 2003), frugal is more related to intrinsic goals and are less worried about social bonds (CorralVerdugo et al., 2011).

Waldinger and Schulz (2010) surveyed social functioning and happiness during many years including quantity and quality of interpersonal connections and found that close and good relationships keep people happier. As a matter of fact, happiness is enabled when humans are skilled to evaluate their social bonds. Therefore, it is evident that important sources of happiness are social behaviors and relationships. Individuals that have trouble forming social relationships despite their desire to do so or who take special caution and consideration of other people's opinions in social situations can be affected. It is thought to be critical to comprehend the relationship between those social behaviors that encourage or undermine the social relationships that provide happiness. 


\subsection{Happiness, materialism, and social anxiety}

The rise of consumer purchasing power, the availability of consumer products, and the increase of the per-capita gross domestic product (GDP) led to a more dependent economy on continuous innovation. However, the Paradox of Happiness (Easterlin, 1974) reassessed by Stevenson and Wolfers (2008) indicates that even with the increase in the GDP, people have not changed their levels of happiness.

Norris and Larsen (2011) and Kasser (2002) identified that happiness is negatively affected by materialistic consumers when these ones want more, i.e., the more we have, the less happy we are. Richins and Dawson (1992) find high levels of wanting more are related to materialists, and these ones reported lower evidence of satisfaction. They also verified that material possessions are not a source of happiness. Moreover, unhappiness is positively related to material possessions (Burroughs \& Rindfleisch, 2002), and Costley et al. (2007) affirm that materialism does not enhance happiness. Some reasons for this negative relationship are (i) the lack of control materialists have over-consumption, and it (i.e., over-consumption) is viewed as an escape (Lee \& Ahn, 2016), and (ii) the permission this consumption plays a pivotal role in their lives (Sirgy, Lee, \& Rahtz, 2007).

Materialism is a way somehow goods assume an important role during one's life. Goldsmith and Clark (2012) argue that materialists are not aware of the amount of money they pay for a good due to the high level of satisfaction they may have when acquiring a new and/or notorious product. These authors believe that these kinds of consumers buy products in order to have social responses, i.e., others may admire them due to the high standard quality goods they have. Kasser (2002) describes that these consumers have low levels of self-esteem. Indeed, this is the reason they buy certain products in order to fill a sentimental gap. Likewise, Dittmar and Pepper (1994) define materialism as an individual's personal and social behavior and evidence that materialistic ones use products to express their personality, social relationships, including social acceptance and status (Goldsmith, Flynn, \& Clark, 2011).

The recognition of social behaviors in consumer society is present in our daily lives. For instance, individuals with higher levels of materialism are prone to behave differently when in public (Wang et al., 2019). There is existential anxiety created for consumption and a sense of a lack of things we can not have or afford (Baumann, 2007). Warde (1994) presented the concept that consumption choices can be anxiety-provoking, and marketing strategies may reduce this behavior. Therefore, anxiety should be considered an emotional state we must work with due to this way of being by the human condition. 
To shed light on social anxiety, American Psychiatric Association (1980) initiated its measures in the 1980s under concerns over social evaluation. Buss (1980) defines social anxiety as a behavioral reaction by concerns with how individuals are perceived and evaluated by others, i.e., a type of anxiety that includes a prospect of interpersonal evaluation in a social situation. It may also be felt by individuals that are faced with new people or situations so that it may provoke avoidance of social situations and issues with their social lives (Sahranç et al., 2018).

Materialism and social anxiety may offer useful insights to scholars and practitioners, a novelty avenue that may lead us to explore possible consequences. Materialists have less selfesteem (Belk, 1985), "social anxiety implies concern over social evaluation" (Schroeder \& Dugal, 1995, p. 245). As a consequence, people concerned with the perception of others tend to be more materialistic.

Hence, we built our first hypothesis (H1), as follows: social anxiety amplifies the negative relationship between happiness and materialism.

\subsection{Happiness, frugality, and hedonism}

Post-modern consumers are involved in materialism and seek to demonstrate their social expresses and feelings through brands and products. Anti-consumption focuses on a strong contrast to materialism, and it rises on motivations against consumption (Loureiro, 2017). According to what we mentioned in the previous section, people are likely to believe that their possessions will lead them to accomplishments and success, which is the opposite. For instance, materialist ones tend to compare themselves to wealthy people, and they are more unhappy due to their voracious desire (Shaw, 2002). Therefore, if the seeking of possessions does not deliver happiness, and if materialists, full of a strong desire for consumption, may lead to a negative relationship in happiness, are anti-consumption individuals happier? In order to reduce these negative effects, anti-consumption rises as a way to adapt to the actual post-modern lifestyle by seeking to reduce consumption.

Anti-consumption individuals are more concerned about issues the society and the environment may have with excessive consumption (Belk, 1988, Iyer \& Muncy, 2009). Moreover, they also believe in a simple lifestyle without overconsumption, and this way of life drives them for intrinsic goals with less stress and self-actualization (Huneke, 2002). Frugality is also considered a type of anti-consumption. 
In line with this idea, frugality is a voluntarily way an individual embraces a simple lifestyle without sumptuary consumption of goods and services. They avoid waste and are likely to control things they possess in a sustainable and responsible way (DeYoung, 1986). Indeed, it is someone that spends wisely as a way to achieving long goals, and it has long been associated with social aspects. Lastovicka et al. (1999) argue that frugality is a useful construct for understanding consumer experience behaviors and frugal consumers distinguish themselves as discipline ones. Likewise, "frugal consumers avoid purchasing higher-priced consumer goods when lower-priced substitutes are available" (Pan et al., 2019, p.347). Thus, frugality is an attribute of the wealthy lifestyle that people save more than spending money (Bove, Nagpal, \& Dorsett, 2009).

Due to frugal behaviors lead to spiritual and social peace (Bouckaert, 2008), we believe that it may also lead to happiness. We may also assume that as long as frugality is also positively linked to anti-consumption, which is negatively correlated to materialism, we also consider that there is a positive relationship between frugal individuals and happiness. Finally, we also understand that there is a positive relationship between frugal and hedonic behaviors because Baumeister, Stillwell, and Heatherton (1994) found that when frugal individuals feel guilty when buying luxury products, they balance this behavior by engaging hedonic sensations.

The etymology of the word hedonism is derived from the Greek word hedone which means enjoyment and pleasure and relates to sensuous gratification for oneself. Likewise, it is viewed as a pleasure-seeking that aspires quality experiences led by patterns of feelings (O'Shaughnessy \& O'Shaughnessy, 2002). Campbell (1987) claims that scholars and practitioners should understand how consumers generate these feelings.

Seminal studies about hedonic consumption were first developed by Hirschman and Holbrook (1982). Hedonism is an important consumer characteristic (Chitturi, Raghunathan, \& Mahajan, 2007), and it refers to the facets of consumer behavior related to the multiple sensorial aspects that evoke a variety of meanings associated with tastes, sounds, smells, tactile impressions, and visual images (Hirschman \& Holbrook, 1982). Thus, hedonic results from "sensations derived from the experience of using a product" (Voss, Spangenberg, \& Grohmann, 2003, p.310). The hedonic consumer is the one who seeks to arouse good feelings through the utility perceived in the purchase of a product without concerns about the norms imposed by a group the individual belongs (Goldsmith \& Clark, 2012).

Furthermore, the merits of hedonism are the pursuit of pleasure, and its benefits lead to (i) reduce stress (Warburton 1996), (ii) contribute to happiness due to the balance of pleasant 
feelings and (iii) make people more sociable (Veenhoven, 2003). Therefore, the last benefit strengthens social bonds and conducts to more pleasurable situations in the future. Indeed, pleasure-seekers may activate higher levels of happiness.

This, our second hypothesis is based on the relationship among happiness, frugality, and hedonism as follows: (H2) hedonism positively moderates the positive relationship between happiness and frugality.

\subsection{Happiness, conspicuous consumption, and social acceptance}

The area of happiness is one that has been relatively neglected by researchers and yet understanding reasons how conspicuous consumption and social acceptance would seem enlightening to academia. Consumption externalities are pivotal in understanding what motivates someone to acquire goods and services. Winkelmann (2012) attributes that own consumption can be influenced by the consumption of others based on conspicuousness or by the strength of social acceptance of consumption and social status (Venkatesh, 1994).

Arslan (2018) define social acceptance as an individual's perception of being included and valued in society and encouraged to be part of the social environment. Moreover, Malone, Pillow and Osman (2012) argue that social acceptance is possibly associated with happiness so that positive emotions may be evoked, such as contentment, joy, and elation.

These emotions and social behaviors seem to be affected by aspirations in emerging countries under the pressure of consumption trends (Shukla, 2012) by spending more on visible goods to be socially accepted among neighbors or relatives (Venkatesh, 1994, Winkelmann, 2012). Likewise, this rate of consumption does not possibly increase the level of satisfaction, well-being, or happiness. For instance, Layard (1980) claims that the net result of statusmotivated action when individuals make sacrifices to improve their social position is dissatisfaction. In addition, people who acquire more of these products are prone to be unhappier and less satisfied with their lives (Winkelmann, 2012).

Conspicuous consumption is defined by the act of buying a variety of services and goods that are often unnecessary and expensive in order to have someone's notice (Shukla, 2011) and the social behavior that shows wealth by luxury consumption of goods and services (Trigg, 2001). Vigneron and Johnson (2004) affirm that conspicuousness plays a significant role in consumer preferences. Indeed, luxury goods influence consumers in fostering social acceptance (Shukla, 2011). Furthermore, one way to identify conspicuous consumption behaviors is by studying socially-oriented motives (Sharma, 2010). O'Cass and McEwen (2004, p. 26) implies 
that "conspicuous consumption tendencies of consumers are important in creating relationships between consumers who possess such characteristics and specific types and brands that yield status" and "consumer's desire for conspicuous goods is still largely determined by their social networks" (p. 28). Therefore, conspicuous consumption can also be viewed as an asocial individualism.

If one wants to be socially approved, the individual should engage in a personal schemata composed of possessions in a significantly visible and personalizable involvement (Richins \& Dawson, 1992; Dittmar \& Pepper, 1994). Social norms influence purchase behaviors, and it is subject to the pressures of the society under the perspective of status and prestige (Belk, 1988). Sheth et al. (1991) argue that there are associations between someone's symbolism and image with socio-economic and demographic groups so that consumers are inclined to be affected by the social prestige and status by acquiring and consuming goods and services. In addition, consumers also use goods to confirm their social relationships and to affirm their personal behaviors (Dittmar \& Pepper, 1994). Goods can signify group membership, may act as the image consumers want to express to others, and can be a way to acquire social status (Goldsmith \& Clark, 2012). Thus, conspicuous consumption moderates social relationships in order to force social acceptance by conspicuousness.

A dominant logic is also explored by the way consumers are susceptible to normative influences which individuals purchase decision need to conform to one's image with products and brands to others' expectancies (Bearden, Netemeyer, \& Teel, 1989). In addition, consumers purchase a specific product by what it represents to themselves and to the others with whom they wanted to be affiliated (Leigh \& Gabel, 1992). It seems that acquiring this specific product is a prerequisite to being accepted by the desired social group.

Consequently, when they fail to successfully obtain a desirable impression, there is the occurrence of social disapproval. Xu and Jin (2020) argue that social exclusion has a negative role on the human need to belong and, in order to avoid it, they sacrifice their happiness for the sake of social well-being (Mead et al., 2010). However, there is a gap in identifying to what extent sacrifice is worthwhile, and the use of moderators is beneficial to find it out. These authors also investigate that socially excluded people spend more to be collectively affiliated again. This connection reveals the keen an individual is likely to do when threatened by social rejection, including consuming conspicuously.

In line with this idea, O'Cass and McEwen (2004) emphasize that conspicuousness is critical when individuals desire to have social acceptance and recognition. Conspicuous 
consumption provides social approval or disapproval, and consuming brands may allow bonds to reference groups (Sullivan \& Harnish, 1990). Indeed, Wong and Ahuvia (1998) state that social networks influence establish individual's wants for conspicuous consumption.

Our last hypothesis is based on the relationship among happiness, social acceptance, and conspicuousness, and after revisiting the literature, we assume the following hypothesis $(\mathrm{H} 3)$ : conspicuousness negatively moderates the positive relationship between Happiness and Social Acceptance.

\section{Method}

\subsection{Data collection, sample size, and calculations}

The sample was based on 197 real consumers in a capital city in Brazil with more than 2.5 million inhabitants. Data was gathered in-person; respondents were randomly intercepted at shopping malls, streets, and grocery stores and were asked to participate in a research study that intended to gauge their behaviors as consumers using personally administered questionnaires. We chose a systematic probabilistic sampling by picking every 10th respondent walking in these places, and all interviewers were standing with a clipboard in hand. The places were chosen based on the demographic distribution of the Brazilian Institute of Geography and Statistics, the governmental agency responsible for the official collection of statistical data in order to mitigate sampling bias. The average time taken to complete the questionnaire was 13 minutes.

In order to verify if our results were significant due to a lack of statistical power, we ran a compromise power analyses using GPower (Erdfelder, Faul, \& Buchner, 1996) with the following paramenters: effect size $\mathrm{f}^{2}=0.15, \beta / \alpha$ ratio $=4$; with 197 respondents and the number of predictors of each model, we obtained a noncentrality paramenter $\lambda=29.55$, critical $\mathrm{F}=4.35$, $\alpha$ error prob $=0.005, \beta$ error prob $=0.021$ and power $(1-\beta)$ set at 0.978 , two-tailed. This showed that there is a high chance of correctly rejecting the null hypothesis of no difference with a total of 197 respondents.

\subsection{Survey instrument and measures}

The survey instrument (see Appendix A) was designed to measure seven variables: happiness, materialism, social anxiety, anti-consumption, frugality, conspicuousness, and social acceptance. It was based on several reliable and valid scales and adapted and translated into the Portuguese language. It is important to note that the Portuguese version of these items 
was adapted and translated by a $\mathrm{PhD}$ in linguistics (English \& Portuguese). For content validity, it was tested and validated by three Marketing experts and a senior Marketing Professor (Dillon, Madden, \& Firtle, 1993). Finally, for face validity, a pretest of the survey instrument was conducted with 20 people. The survey instrument required no further changes following the pretest screening process.

To measure happiness, participants reported the four-item Subjective Happiness Scale - SHS (Lyubomirsky \& Lepper, 1999). Social Anxiety was measured by asking participants to indicate how strongly they relate their anxiety (Mattick \& Clarke, 1998). The Materialism survey included the six-item materialism scale proposed by Richins (2004). The eight-item Frugality Scale was based on Lastovicka et al. (1999) and respondents used a seven-point Likert-type scale (1- Strongly Disagree, 7-Strongly Agree).

To measure Hedonism, we used the eleven-item scale developed by Babin, Darden, and Griffin (1994), and for Social Acceptance, we used the normative consumer susceptibility to interpersonal influence seven-item scale from Bearden, Netemeyer, and Teel (1989). The last scale we used in our study was about Conspicuousness based on the conspicuous value scale by Shukla (2012).

\subsection{Method}

The survey was divided into three blocks for each hypothesis (H1 to H3) and in two steps for each block. In the first step, a confirmatory factor analysis was used to test the measurement model. We used IBM AMOS to perform this step in order to understand the multidimensional nature of each construct. We also assessed convergent and discriminant validity following Anderson and Gerbing's (1988) criteria. In the second step, we used the Model 1 of the Process Module (Hayes, 2013), using 10,000 bootstrap samples to assess whether the differences, directions, and interactions among variables were statistically significant including the Johnson-Neyman technique which shows where the simple effect is significant or not (Johnson \& Fay, 1950).

This technique is extremely useful in moderation due to the possibility of identifying the regions of the significance of the effect of $\mathrm{X}$ on $\mathrm{Y}$ along the continuum of the dimension measured by M (Hayes \& Matthes, 2009). It also provides a wider view of the areas where moderation has a major effect, and the 95 percent confidence bands along the simple regression axis, which defines the region(s) of importance, are also used in this technique. Therefore, this technique "identifies the value or values within the measurement range of the moderator, if they 
exist, where the conditional effect of $\mathrm{X}$ transitions between statistically significant and not using a chosen $\alpha$-level of significance" (Hayes, 2012, p.16).

\subsection{Descriptive statistics}

At the end of the survey, respondents were also asked a set of personal questions. Of the 197 respondents, 97 (49.2\%) were male and 100 (50.8\%) were female. Respondent ages varied from 18 to more than 52, $94(47.7 \%)$ were between 18 and 25 years old, 47 (23.9\%) were between 26 and 34 years old, 39 (19.8\%) were between 35 and 43 years old, 6 (3\%) were between 44 and 52 years old, and finally 11 (5.6\%) were older than 52 years old. We also asked about their annual family incomes. Of the 197 respondents, 29 (14.7\%) earn less than USD7,621.00 a year, $87(44.2 \%)$ between USD7,622.00 and USD22,864.00, 34 (17.3\%) between USD22,685.00 and USD34,296.00, and finally, 47 (23.9\%) earn more than USD34,296.00 a year.

\section{Results}

Prior to testing the hypothesized relationships and their interpretations of findings, we tested the variables for multicollinearity. Bivariate correlations between variables were all below 0.80 and statistically significant. The highest correlation was between Social Anxiety and Materialism with 0.76 . We also ran a canonical correlation test among all variables and the $\mathrm{F}$ test was 75.345 with seven degrees of freedom, correlation equals to 0.758 , Wilks Lambda $=$ 0.264 and $p<0.001$. These results suggest that multicollinearity is not an issue in our data (Tabachnick \& Fidell, 2001). Descriptive statistics and bivariate correlations for all the composite variables are presented in Table 1.

Table 1 - Descriptive statistics and bivariate correlations

\begin{tabular}{llllllllll}
\hline Variables & Mean & $\begin{array}{l}\text { Standard } \\
\text { Deviation }\end{array}$ & $\mathbf{1}$ & $\mathbf{2}$ & $\mathbf{3}$ & $\mathbf{4}$ & $\mathbf{5}$ & $\mathbf{6}$ & $\mathbf{7}$ \\
\hline 1.Happiness & 4.48 & 1.23 & $(0.86)$ & & & & & & \\
2.Materialism & 3.96 & 1.77 & $-0.39^{* *}$ & $(0.77)$ & & & & & \\
3.Social Anxiety & 3.68 & 1.60 & $-0.40^{* *}$ & $0.76^{* *}$ & $(0.86)$ & & & & \\
4.Frugality & 4.51 & 1.87 & $0.65^{* *}$ & $-0.25^{* *}$ & $0.23^{* *}$ & $(0.89)$ & & & \\
5.Hedonism & 5.17 & 1.18 & $0.45^{* *}$ & $-0.18^{*}$ & $0.20^{* *}$ & $0.05^{\#}$ & $(0.92)$ & & \\
6.Conspicuousness & 2.70 & 1.44 & $-0.37^{* *}$ & $0.11^{\#}$ & $0.10^{\#}$ & $0.31^{* *}$ & $0.18^{* *}$ & $(0.88)$ & \\
7.Social Acceptance & 3.76 & 1.34 & $0.27^{* *}$ & $-0.04^{\#}$ & $-0.61^{\#}$ & $0.17^{*}$ & $0.15^{*}$ & $0.002^{\#}$ & $(0.92)$ \\
\hline
\end{tabular}

Note: Figures in parentheses are Cronbach's alphas.

**Correlation is significant at the 0.01 level (2-tailed). *Correlation is significant at the 0.05 level (2-tailed). \#Correlation is not significant.

Source: The authors. 
The quality of the measurement model of reliability, convergent and discriminant validities are examined in this section. These were measured by examining the composite reliability $(\mathrm{CR})$ values to analyze reliability $(\mathrm{CR}>0.70)$, and maximum reliability $(\mathrm{Max}(\mathrm{H})$ $(\operatorname{Max}(\mathrm{H})>\mathrm{CR})$; average variance extracted $(\mathrm{AVE})$ values to analyze the convergent validity $(\mathrm{AVE}>0.5$ and $\mathrm{CR}>\mathrm{AVE})$; and maximum shared square variance (MSV), average shared square variance (ASV) and square root of AVE (SQRT AVE) to check the discriminant validity (MSV < AVE, ASV < AVE and SQRT AVE > the highest inter-construct correlations with any other variables) (Fornell \& Larcker, 1981). The data obtained can be seen in Table 2.

Table 2 - Reliability, Convergent and discriminant validities

\begin{tabular}{llllllllllll}
\hline & CR & AVE & MSV & MaxR(H) & 1 & $\mathbf{2}$ & $\mathbf{3}$ & $\mathbf{4}$ & $\mathbf{5}$ & $\mathbf{6}$ & $\mathbf{7}$ \\
\hline 1.Happiness & 0.775 & 0.683 & 0.338 & 0.795 & $(0.733)$ & & & & & & \\
2. Materialism & 0.706 & 0.613 & 0.154 & 0.745 & -0.227 & $(0.620)$ & & & & & \\
& & & & & & & & & & & \\
3.Social Anxiety & 0.884 & 0.602 & 0.154 & 0.899 & -0.392 & 0.310 & $(0.680)$ & & & & \\
4. Frugality & 0.917 & 0.670 & 0.230 & 0.931 & 0.070 & -0.215 & -0.077 & $(0.728)$ & & & \\
5. Hedonism & 0.911 & 0.700 & 0.234 & 0.935 & 0.030 & 0.480 & 0.168 & -0.232 & $(0.774)$ & & \\
6.Conspicuousness & 0.812 & 0.691 & 0.338 & 0.819 & -0.150 & 0.581 & 0.267 & -0.246 & 0.372 & $(0.768)$ \\
7. Social & & & & & & & & & & & \\
Acceptance & 0.876 & 0.643 & 0.061 & 0.882 & -0.143 & 0.435 & 0.363 & -0.227 & 0.389 & 0.484 & $(0.799)$
\end{tabular}

Note: Figures in parentheses are square root of AVE (SQRT AVE).

Source: The authors.

We also used common method bias (CMB) to identify the variance of all variables in the measurement model and we obtained 0.211. According to Podsakoff et al. (2003) and Siemen et al. (2009), it is a technique to be used with interaction regression models, and the $\mathrm{CMB}$ is considered without correlation issue if less than 0.5. Finally, the indicators presented by the CFA were verified and evidenced the validation of the model. The proposed model shows a positive general adjustment: $\mathrm{GFI}=0.904, \mathrm{IFI}=0.923, \mathrm{TLI}=0.913, \mathrm{CFI}=0.922, \mathrm{RMSEA}=0.049$, e $\chi^{2}=1039.151, \mathrm{df}=705\left(\chi^{2} / \mathrm{df}=1.474 ; \mathrm{p}=0.000\right)$. The ratio of the chi-square on degree levels of freedom is within the recommended reach of 3:1 for the adjusted models (Kline, 1998).

\section{Hypotheses Test}

We conducted the analyses using multiple linear regression, with happiness meancentered (Y). The independent variables in the regression equation were the covariates (a) 
Materialism (X) and Social Anxiety (M), and the Materialism and Social Anxiety interaction (XM) for H1; (b) Frugality (X) and Hedonism (M), and the Frugality and Hedonism interaction (XM) for H2; (c) Social Acceptance (X) and Conspicuousness (M), and the Social Acceptance and Conspicuousness interaction (XM) for $H 3$, as it follows: $Y=a+b_{1} X+b_{2} M+b_{3} X M$.

We also added the Johnson-Neyman technique for the three hypotheses in order to identify the exact point where the value of $\mathrm{X}$ for the simple effect of $\mathrm{M}$ is statistically significant. Therefore, the values of $\mathrm{X}$ on one side of the Johnson-Neyman point generate significant differences between the two sides. We emphasize that the other side is not significant so that we can have a better understanding of the range of values of the continuous predictor $\mathrm{X}$ for which the group differences are statistically significant on the moderator (Spiller et al., 2012). This technique provides a specific comprehension on the continuous measure of the moderator and presents the results of the range over which the simple effect is significant rather than points without meaning. Here is the equation 1 to obtain the $t$ critical for $p<0.001$.

$$
t_{c r i t}=\frac{b_{1}+b_{3} M}{\sqrt{s e_{b 1}^{2}+(2 M) \operatorname{Cov}_{b 1 b 3}+M^{2} s e_{b 3}^{2}}}
$$

Source: Hayes (2013, p. 240).

\section{H1: Social anxiety amplifies the negative relationship between happiness and materialism.}

In line with our first hypothesis (H1) - social anxiety amplifies the negative relationship between happiness and materialism, we depicted Figure 1 for a better understanding of the relationships before presenting the results.

Figure 1 - H1: Relationship between Happiness, Materialism and Social Anxiety

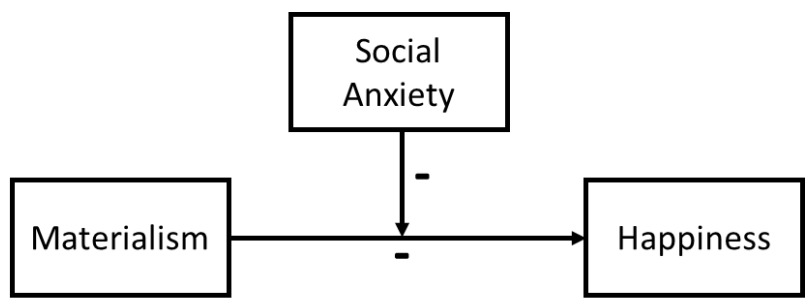


Source: The authors.

The moderation regression effects on happiness (see Table 3) showed significant $\mathrm{F}(3,193)=19.8422, \mathrm{p}<0.001, \mathrm{R}^{2}=0.2185$, effects of Materialism $(\beta=-0.1766), \mathrm{t}(193)=-$ $2.5639, \mathrm{p}=0.111)$, Social Anxiety $(\beta=-0.1678, \mathrm{t}(193)=-2.2049, \mathrm{p}=0.029)$, and the Materialism x Social Anxiety interaction $(\beta=-0.0915, \mathrm{t}(193)=-3.1000, \mathrm{p}=0.022)$. Thus, for every one unit of Materialism, participants get a 0.1766 unit decrease in Happiness and for every one unit of Social Anxiety, they get a 0.1678 unit decrease in Happiness.

Table 3 - Happiness, Materialism, and Social Anxiety Moderation Model

\begin{tabular}{ccccc}
\hline & & Coeff. & SE & p \\
\hline Intercept & $\mathrm{i}_{1}$ & 4.6793 & 0.1007 & $<0.001$ \\
Materialism & $\mathrm{b}_{1}$ & -0.1766 & 0.0689 & 0.111 \\
Social Anxiety & $\mathrm{b}_{2}$ & -0.1678 & 0.0761 & 0.029 \\
Materialism x Social Anxiety & $\mathrm{b}_{3}$ & -0.0915 & 0.0295 & 0.022 \\
& $\mathrm{R}^{2}=0.2185$, MSE $=1.2057, \mathrm{~F}(3,193)=19.8422, \mathrm{p}<0.001$ & \\
\hline
\end{tabular}

Source: The authors.

For understanding the slopes for Materialism predicting happiness at each level of Social Anxiety (see Figure 2), we have the following outcomes: (i) for low levels of Social Anxiety, Materialism $\beta=-0.0305, \mathrm{t}(193)=-0.3878, \mathrm{p}=0.6986$ (not significant) $\rightarrow$ for low levels of Social Anxiety, there is no relationship between Materialism and Happiness; (ii) for average levels of Social Anxiety, Materialism $\beta=-0.1766, \mathrm{t}(193)=-2.5639, \mathrm{p}=0.0111$ (significant) $\rightarrow$ for average levels of Social Anxiety, every unit of Materialism reduces 0.1766 the level of happiness; and (iii) for high levels of Social Anxiety, Materialism $\beta=-0.3228$, $t(193)=-3.6648, p=0.0003$ (significant) $\rightarrow$ for high levels of Social Anxiety, every unit of Materialism reduces 0.3228 the level of happiness.

The Johnson-Neyman technique indicates that when levels of Social Anxiety is at least 3.20, Materialism and Happiness are significantly related, $\mathrm{t}(193)=-1.9723, \mathrm{p}=0.05, \beta=-$ 0.1352. As levels of Social Anxiety increases, the relationship between Materialism and Happiness becomes more negative with the highest levels of Social Anxiety (7 times greater), $\beta=-0.4805, \mathrm{t}(193)=-3.7994, \mathrm{p}<0.01$. Participants with high levels of Materialism and Social Anxiety are more prone to reduce their happiness with a negative slope in comparison to the 
low levels of Materialism. Thus, Social Anxiety amplifies the negative relationship between Happiness and Materialism and the interaction effects hypothesized in $\mathrm{H} 1$ is confirmed.

Figure 2 - Hypothesis 1: Happiness by Materialism and Social Anxiety

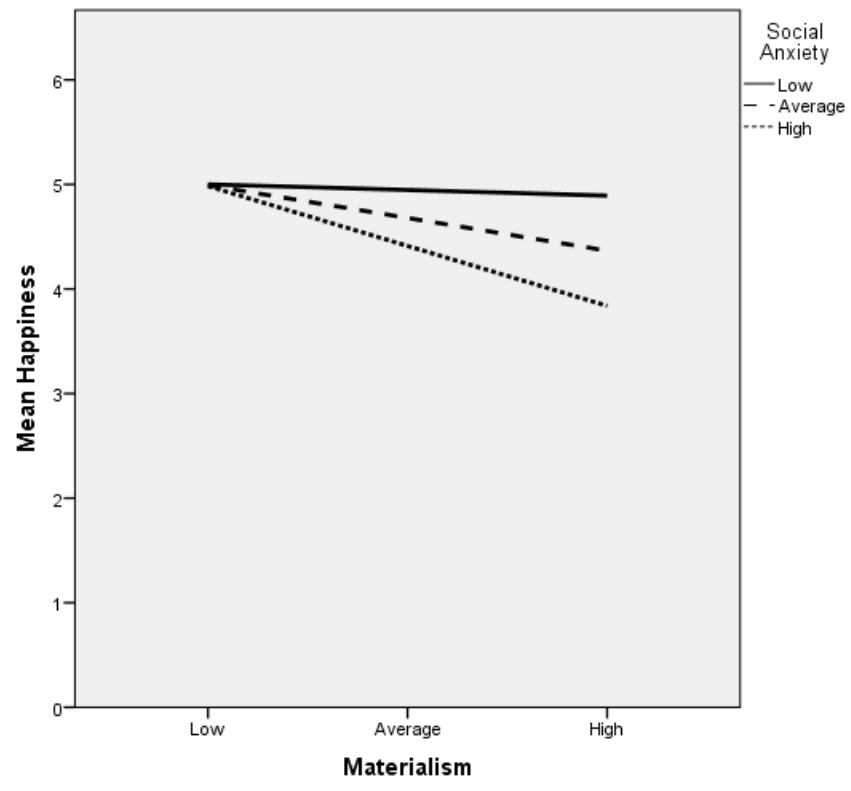

Source: The authors.

H2: Hedonism positively moderates the positive relationship between happiness and frugality.

Figure 3 represents our second hypothesis (H2) - Hedonism positively moderates the positive relationship between happiness and frugality. The relationship in this figure emphasizes the way both variables (Hedonism and frugality) amplify positive levels of happiness.

Figure 3 - H2: Relationship between Happiness, Hedonism and Frugality

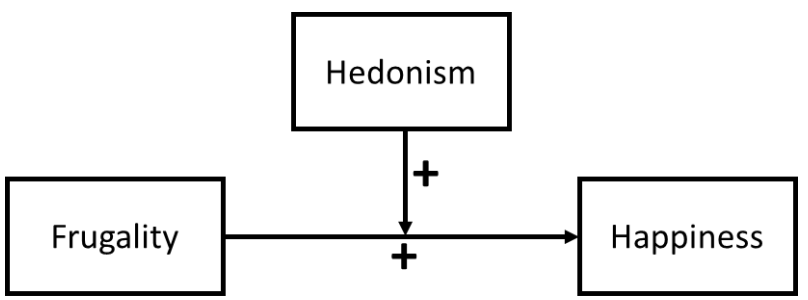


Source: The authors.

The moderation regression effects on happiness (see Table 4) showed significant $F(3,193)=162.1650, p<0.001, R^{2}=0.6117$, effects of Frugality $(\beta=0.4337, t(193)=13.8381$, $\mathrm{p}<0.001)$, Hedonism $(\beta=0.4641, \mathrm{t}(193)=11.1564, \mathrm{p}<0.001)$, and the Frugality $\mathrm{x}$ Hedonism interaction $(\beta=0.0447, \mathrm{t}(193)=2.1457, \mathrm{p}=0.0331)$. Thus, for every one unit of Hedonism, participants get a 0.4641 unit increase in Happiness and for every one unit of Frugality, they get a 0.4337 unit increase in Happiness.

Table 4 - Happiness, Frugality, and Hedonism Moderation Model

\begin{tabular}{ccccc}
\hline & & Coeff. & SE & p \\
\hline Intercept & $\mathrm{i}_{1}$ & 4.4780 & 0.0552 & $<0.001$ \\
Frugality & $\mathrm{b}_{1}$ & 0.4337 & 0.0308 & $<0.001$ \\
Hedonism & $\mathrm{b}_{2}$ & 0.4641 & 0.0483 & $<0.001$ \\
Frugality x Hedonism & $\mathrm{b}_{3}$ & 0.0447 & 0.0224 & 0.0331 \\
& \multicolumn{2}{c}{$\mathrm{R}^{2}=0.6117, \mathrm{MSE}=0.5990, \mathrm{~F}(3,193)=162.1650, \mathrm{p}<0.001$} & \\
\hline
\end{tabular}

Source: The authors.

For understanding the slopes for Frugality predicting happiness at each level of Hedonism (see Figure 4), we have the following outcomes: (i) for low levels of Hedonism, Frugality $\beta=0.3807, \mathrm{t}(193)=12.8601, \mathrm{p}<0.001$ (significant) $\rightarrow$ for low levels of Hedonism, every unit of Frugality increases 0.3807 the level of happiness; (ii) for average levels of Hedonism, Frugality $\beta=0.4337, \mathrm{t}(193)=13.8381, \mathrm{p}<0.001$ (significant) $\rightarrow$ for average levels of Hedonism, every unit of Frugality increases 0.4337 the level of happiness; and (iii) for high levels of Hedonism, Frugality $\beta=0.4867, \mathrm{t}(193)=10.1311, \mathrm{p}<0.001$ (significant) $\rightarrow$ for high levels of Hedonism, every unit of Frugality increases 0.4867 the level of happiness. Participants with high levels of Frugality and Hedonism have higher levels of happiness with a positive slope in comparison to the low levels of Frugality and Hedonism. Therefore, Hedonism moderates the positive relationship between Happiness and Frugality and the interaction effects hypothesized in $\mathrm{H} 2$ is confirmed.

The Johnson-Neyman technique indicates that there are no statistical significance transition points within the observed range of the moderator. Indeed, the conditional effect of $\mathrm{X}$ on $\mathrm{Y}$ is statistically significant across the entire range of the moderator (see slopes in Figure 
4). In other words, the difference in Frugality across the low and high levels of Hedonism is significant across values of happiness.

Figure 4 - Hypothesis 2: Happiness by Frugality and Hedonism

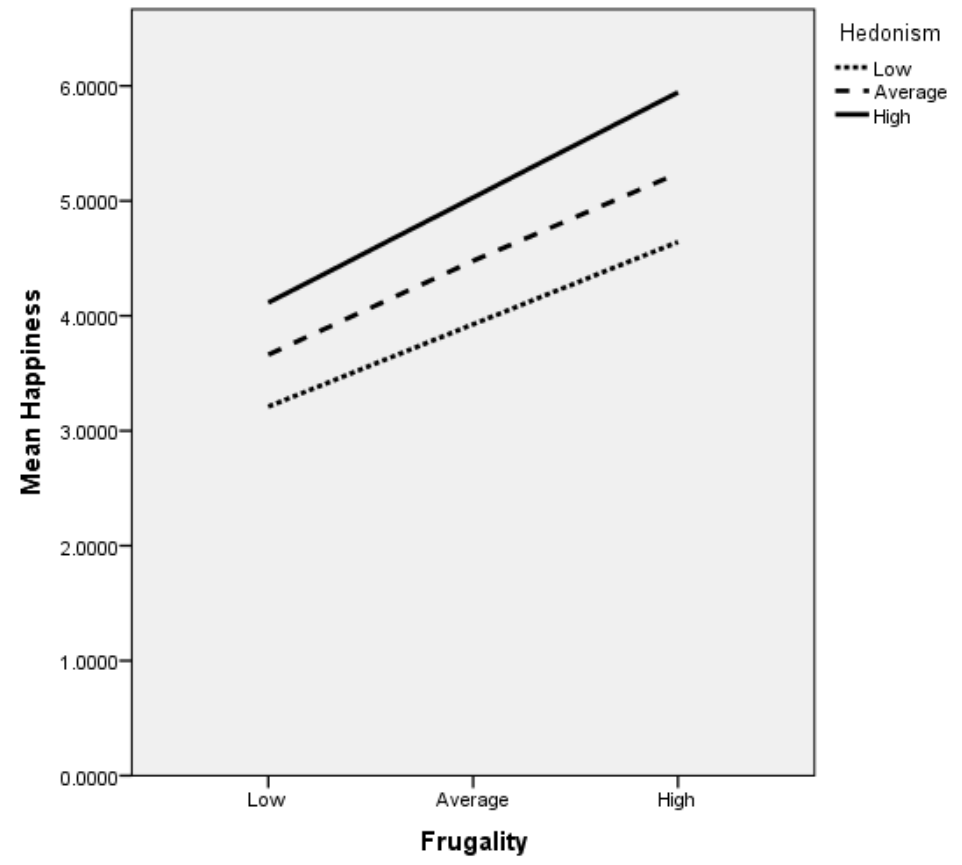

Source: The authors.

\section{H3: Conspicuousness negatively moderates the positive relationship between Happiness and}

\section{Social Acceptance.}

Figure 5 represents our last hypothesis (H3) - conspicuousness negatively moderates the positive relationship between Happiness and Social Acceptance. This figure highlights a negative interaction (conspicuousness) between a positive relationship (Happiness and social acceptance) so that one reduces the strong relationship of the other.

Figure 5 - H3: Relationship between Happiness, Conspicuouness and Social Acceptance 


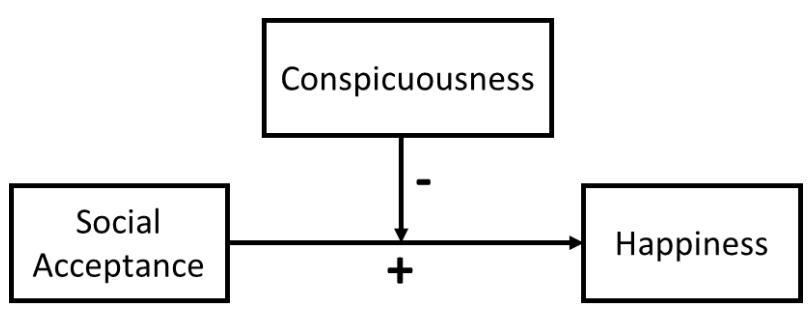

Source: The authors.

The moderation regression effects on happiness (see Table 5) showed significant $\mathrm{F}(3,193)=19.4094, \mathrm{p}<0.001, \mathrm{R}^{2}=0.2318$, effects of Social Acceptance $(\beta=0.2452, \mathrm{t}(193)=$ 4.0967, $\mathrm{p}<0.001$, Conspicuousness $(\beta=-0.3001, \mathrm{t}(193)=-4.7741, \mathrm{p}<0.001)$, and the Conspicuousness $x$ Social Acceptance interaction $(\beta=-0.0787, \mathrm{t}(193)=-2.0598, \mathrm{p}=0.0408)$. Thus, for every 1 unit of Social Acceptance, participants get a 0.2452 unit increase in Happiness and for every 1 unit of Conspicuousness, we get a -0.3001 unit decrease in Happiness.

Table 5 - Happiness, Social Acceptance, and Conspicuousness Moderation Model

\begin{tabular}{ccccc}
\hline & & Coeff. & SE & p \\
\hline Intercept & $\mathrm{i}_{1}$ & 4.4828 & 0.0776 & $<0.001$ \\
Social Acceptance & $\mathrm{b}_{2}$ & 0.2452 & 0.0579 & $<0.001$ \\
Conspicuousness & $\mathrm{b}_{1}$ & -0.3001 & 0.0546 & $<0.001$ \\
$\begin{array}{c}\text { Conspicuousness x Social } \\
\text { Acceptance }\end{array}$ & $\mathrm{b}_{3}$ & -0.0787 & 0.0337 & 0.0408 \\
& $\mathrm{R}^{2}=0.2318, \mathrm{MSE}=1.1852, \mathrm{~F}(3,193)=21.3528, \mathrm{p}<0.001$ & \\
\hline
\end{tabular}

Source: The authors.

For understanding the slopes for Social Acceptance predicting happiness at each level of Conspicuousness (see Figure 6), we have the following outcomes: (i) For low levels of Conspicuousness, Social Acceptance $\beta=0.3583, \mathrm{t}(193)=4.8161, \mathrm{p}<0.001$ (significant) $\rightarrow$ for low levels of Conspicuousness, every unit of Social Acceptance increases 0.3583 the level of happiness; (ii) for average levels of Conspicuousness, Social Acceptance $\beta=0.2452, \mathrm{t}(193)=$ $4.2368, \mathrm{p}<0.001$ (significant) $\rightarrow$ for average levels of Conspicuousness, every unit of Social Acceptance increases 0.2452 the level of happiness; and (iii) for high levels of Conspicuousness, Social Acceptance $\beta=0.1320, \mathrm{t}(193)=1.7254, \mathrm{p}=0.0861$ (not significant) $\rightarrow$ for high level of Conspicuousness, there is no relationship between Social Acceptance and Happiness. 
The Johnson-Neyman technique indicates that when levels of Conspicuousness is at least 3.97, Social Acceptance and Happiness are significantly related, $t(193)=1.9723, p=0.05$, $\beta=0.1443$. As levels of Conspicuousness decreases, the relationship between Social Acceptance and Happiness becomes more positive with the lowest levels of Conspicuousness, $\beta=0.3789, \mathrm{t}(193)=4.7222, \mathrm{p}<0.001$. Hence, Conspicuousness negatively moderates the positive relationship between Happiness and Social Acceptance and the interaction effects hypothesized in H3 is confirmed. Interestingly, participants with low or average levels of Conspicuousness tend to a positive relationship of Social Acceptance and Happiness.

Figure 6 - Hypothesis 3: Happiness by Social Acceptance and Conspicuousness

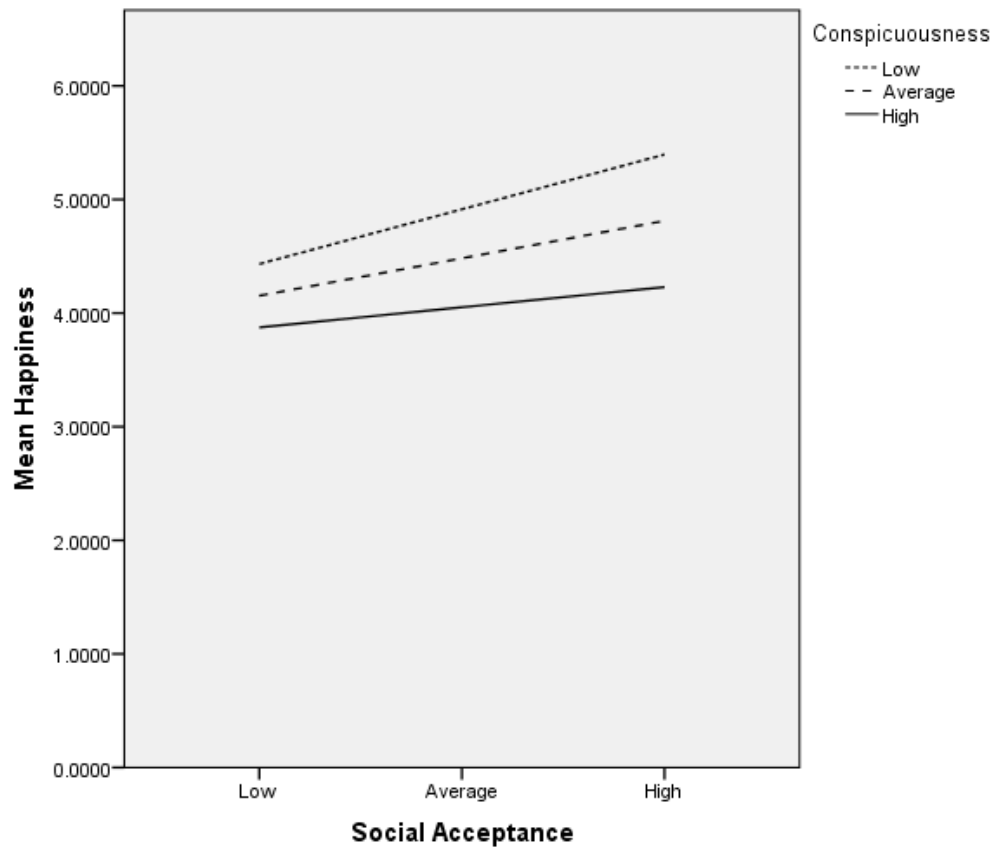

Source: The authors.

\section{Discussion}

Deriving on the theory of happiness, consumption, and social behaviors, we propose a novelty research based on three studies to fill this gap. Social factors such as materialism, social anxiety, frugality, hedonism, conspicuousness, and social acceptance were associated with happiness. Supporting this view, we found that our three hypotheses were corroborated with the literature and our investigation provides numerous contributions to happiness research.

For the first hypothesis, both materialism and social anxiety decrease levels of happiness. The current findings corresponded to previous studies (e.g., Costley et al., 2007; 
Kasser, 2002). Therefore, materialistic consumers that are eager to want more possessions and focus on consumption as a mission of their lives are unhappy due to not having all the things they really wanted to have. The same negative way social anxiety provokes on happiness. If an individual is afraid of being evaluated by others and does not feel comfortable in new situations, we may attribute this situation to a social anxiety (Sahranç et al., 2018). As we can see in Table 3 , the $b_{1}$ and $b_{2}$ coefficients are significant and they influence in almost the same strengthen into happiness.

The present study revealed the moderating effect of social anxiety on the influence of materialism on happiness and provides several new insights at both the theoretical and practical levels. First, we introduced the social behavior social anxiety to understand the association between materialism and happiness which is a novelty way to figure out these social factors. By focusing specifically on social anxiety as a moderator, we provided a more specific foundation for understanding social differences in happiness. As we can see in Figure 2 and the Johnson-Neyman technique, only for average and high levels of social anxiety, the slopes of the relationship between materialism and happiness are significant and they amplified into a negative and strong direction. Individuals that belong to this kind of behavior must be focused by firms due to elaborating strategies to make their customers use their brands in order to reinforce their self-esteem. Therefore, there is a threshold of not stimulating the materialism.

The second hypothesis derives in an opposite side of materialism as we related the association of frugality and hedonism with happiness. Frugal consumers are happier because they wisely spend money (Bove, Nagpal, \& Dorsett, 2009) and hedonic consumers as well (Voss, Spangenberg, \& Grohmann, 2003). The linear multiple regression coefficients are positive as we can see in Table 4 which strengthens both frugality and hedonism relationships.

The interaction is also positive in all levels of moderation role of hedonism. On the one hand, firms may guarantee that their customers must be pleasured to use their products and brands; on the other hand, customers may be smarter in buying only what is necessary. The strategies of the firms must focus on communicating that their brands may make the difference in positive emotions and it is worth acquiring their goods and/or services. Thus, brands may carry out with their customers the use of experiences and sensations.

The last hypothesis investigated the relationship between happiness, social acceptance, and conspicuous consumption. Arslan (2018) agrees that if one feels to be part of the society and socially valued, the levels of happiness of this person tend to be higher. However, people develop some tactics to be socially accepted and one of way is to acquire goods/services that 
create association or relationship with a social environment (Winkelmann, 2012). The outcomes of our research demonstrate that when someone forces and sacrifices himself/herself to buy something, it leads to an overall unhappiness (Layard, 1980). Thus, if this action is solely to demonstrate an artificial social position, i. e., show snobbishness, it is prone to provoke unhappiness feelings.

The moderation role of social acceptance of the relationship between conspicuousness and happiness shed a light on how someone may express a self-image or personal traits under pressures or social norms (Belk, 1988). Our results indicate that for low and average levels of conspicuousness are statically significant the relationship between social acceptance and happiness. It means that high conspicuous consumers do not feel happy when social acceptance is forced by acquiring products in order to belong to a social group. Firms may be parsimonious about how the image of their brands elaborates a diffuse distortion of consumer's minds or even how society perceives that brand as a supercilious one. Therefore, firms must build brand engagement in order to provide social bonds with their customers.

\section{Final remarks}

Happiness is considered the engine of life for humans and a complex subject to study due to several tentacles of comprehension. We hope to contribute to the literature by clarifying the moderation roles of social factors consumption on happiness. Specifically, we examined the moderating roles of social behaviors (social anxiety and conspicuousness) and consumption factors (hedonism) on the relationship between happiness and consumption (materialism and frugality) and social (social acceptance) behaviors. Our findings prove that social anxiety amplifies the negative relationship between happiness and materialism (H1), hedonism positively moderates the positive relationship between happiness and frugality $(\mathrm{H} 2)$, and conspicuousness negatively moderates the positive relationship between happiness and social acceptance $(\mathrm{H} 3)$.

First, we provide evidence that social anxiety amplifies the negative relationship between happiness and materialism (H1). Given that people concerned with the perception of others tend to be more materialistic, our findings suggest that concern over social evaluation makes the negative impact of materialism on happiness stronger.

Second, we provide evidence that hedonism amplifies the positive relationship between happiness and frugality (H2). Given that frugal behaviors lead to spiritual and social peace, and consequently to happiness, our findings suggest that hedonism, related to the pursuit of pleasure 
and stress reduction (Warburton, 1996), strengthens the positive relationship between frugality and happiness.

Finally, we provide evidence that conspicuousness negatively moderates the positive relationship between happiness and social acceptance $(\mathrm{H} 3)$. As social acceptance is defined as an individual's perception of being included and valued in society and encouraged to be part of the social environment (Malone, Pillow, \& Osman, 2012), it may lead to happiness. Our findings suggest that conspicuous consumption, important in creating relationships between consumers who possess such characteristics and specific types and brands that yield status, amplifies the positive relationship between happiness and social acceptance since when those consumers successfully obtain a desirable impression, they obtain social approval (Xu \& Jin, 2020).

To the best of our knowledge, there is no study yet on the simultaneous effects of happiness on consumption and social behaviors (Jaunky et al., 2020). Our paper adds to the literature on happiness by clarifying those issues from an emerging country perspective. Our findings empirically implicate levels of consumer's social behaviors as a key factor in the relationship between happiness and consumption. Those findings not only provide understandings on what makes strengthens such relationship but also provide the inflection point where each of these variables reacts with each other. For instance, due to our outcomes, firms know that they can position their brands in a premium market, but consumers cannot have the feeling of snobbish when using it. The reason is not only based on how the others perceive them but how the consumers perceive themselves. Hence, we contributed to firms idealize new movements in the marketplace.

Our findings suggest that companies must recognize levels of social behaviors. Specifically, the extent to which firms can ensure that consumers react by different levels of these factors while consuming brands may, at the same time, bring some effort to brand engagement, social bonds to their parties, experience joy, and attract new customers.

Although we obtained important outcomes, of course, our study is not without limitations. First, the data of the research were obtained by only one city. In further research, a group analysis could be included in the methodology. For instance, Meisenberg and Woodley (2015) compared happiness and life satisfaction in several countries so that a cross-cultural comparison could be taken, and the analyses should provide how these social behaviors differ into paths of the regression for each specific country or culture. 
Despite cultural issues are not the emphasis of our study, we also want to mention that happiness, frugality, social acceptance, hedonism, materialism, social anxiety, and conspicuousness may have different meanings in different cultures. In line with that, it is important to understand that the meaning of all these constructs may also differ from culture to culture, for old and young people, and with individuals high and low wages as well. Thus, parsimonious interpretations must be taken when carrying out surveys or experiments in different cultures, ages, and social classes.

Another limitation is due to the survey method, which was descriptive research; we believe that carrying out experimental research could be eliminated this limitation. The other limitation, as we are dealing with social behaviors while respondents were randomly selected to answer the questionnaire, we could apply a psychological inventory in order to clarify the mood of all respondents. These bad feelings may provoke unclear and undesirable answers. Although such limitations existed, this study discovered that social behaviors reveal the prediction of happiness, and in the way different levels of each social factor interfere in levels of happiness, which we believe we filled a gap in the literature.

Future studies should investigate the mediating and moderating roles of other social factors in the context of happiness, such as wealth, self-orientation, conformity, and selfindependence. Another intriguing study should lie on investigating a cause-effect relationship between social behaviors and purchase intention mediated by happiness. McFerran et al. (2014) state that there is a positive relationship between happiness and intention to purchase. However, this proposing mediating role could add more details. Moreover, future studies should also understand how these social behaviors can cause prosocial behaviors in consumers. Finally, the present analysis thus highlights both avenues for future research and managerial implication steps through which happiness might be ideal for humans and strategical for firms.

\section{Acknowledgment}

This research is the result of a postdoctoral study sponsored by FGV-EAESP and financially supported by CAPES

\section{References}

American Psychiatric Association (1980). Diagnostic and statistical manual of mental disorders. 3rd ed., Washington, DC: Author.

Anderson, J. C., Gerbing, D. W. (1988). Structural equation modeling in practice: a review and recommended two-step approach. Psychological Bulletin, 103, 411-23. 
Arslan, G. (2018). Psychological Maltreatment, Social Acceptance, Social Connectedness, and Subjective Well-Being in Adolescents. Journal of Happiness Studies, 19(4), 983-1001.

Audette, A.P., Lam, S., O'Connor, H. Radcliff, B. (2018). (E)Quality of Life: A CrossNational Analysis of the Effect of Gender Equality on Life Satisfaction. Journal of Happiness Studies. (first online) https://doi.org/10.1007/s10902-018-0042-8.

Babin, B. J., Darden, W. R., Griffin, M. (1994). Work and/or Fun: Measuring Hedonic and Utilitarian Shopping Value. Journal of Consumer Research, 20(4), 644-656.

Baumann, Z. (2007). Collateral casualties of consumerism. Journal of Consumer Culture, $7(1), 25-56$.

Baumeister, R. F., Leary, M. R. (1995). The need to belong: Desire for interpersonal attachment as a fundamental human motivation. Psychological Bulletin, 117(3), 497-529.

Baumeister, R. F., Stillwell, A. M., Heatherton, T. F. (1994). Guilt: An Interpersonal Approach. Psychological Bulletin, 115(2), 243-267.

Bearden, W. O., Netemeyer, R. G., Teel, J. E. (1989). Measurement of Consumer Susceptibility to Interpersonal Influence. Journal of Consumer Research, 15(4), 473-481.

Belk, R.W. (1985). Materialism: Trait aspects of living in the material world. Journal of Consumer Research, 12(3), 265-280.

Belk, R.W. (1988). Possessions and the Extended Self. Journal of Consumer Research, 15(2), 139-168.

Blackhart, G. C., Nelson, B.C., Knowles, M., L. \& Baumeister, R., F. (2009). Rejection elicits emotional reactions but neither causes immediate distress nor lowers self-esteem: a metaanalytic review of 192 studies on social exclusion. Personality and Social Psychology Review, 13(4), 269-309.

Bögenhold, D., \& Naz, F. (2018). Money, Consumption and Happiness. In Consumption and Life-Styles (pp. 87-102). Palgrave Pivot, Cham.

Bouckaert, L. (2008). Rational versus spiritual concepts of frugality. In L. Bouckaert, H. Opdebeeck and L. Zsolnai (Eds.), Frugality. Rebalancing Material and Spiritual Values in Economic Life, Bern: Peter Lang, pp. 27-43.

Bove, L. L., Nagpal, A., Dorsett, A. D. S. (2009). Exploring the determinants of the frugal shopper. Journal of Retailing and Consumer Services, 16(4), 291-297.

Burroughs, J. E., Rindfleisch, A. (2002). Materialism and well-being: A conflicting values perspective. Journal of Consumer Research, 29(3), 348-370.

Buss, A. H. (1980). Self-consciousness and social anxiety. New York: W. H. Freeman.

Campbell, C. (1987). The Romantic Ethic and the Spirit of Modern Consumerism, Basil Blackwell, Oxford. 
Chitturi, R., Raghunathan, R., Mahajan, V. (2007). Form versus function: How the intensities of specific emotions evoked in functional versus hedonic trade-offs mediate product preferences. Journal of Marketing Research, 44(4), 702-714.

Corral-Verdugo, V., Mireles-Acosta, J., Tapia-Fonllem, C., Fraijo-Sing, B. (2011). Happiness as correlate of sustainable behavior: a study of pro-ecological, frugal, equitable and altruistic actions that promote subjective well-being. Research in Human Ecology, 18(2), 95-104.

Costley, C. Friend, L., Messe, E., Ebbers, C., Wang, L.-J. (2007). Happiness, Consumption, and Being. In: Belk, R. and Sherry Jr., J. F. (Ed.), Consumer Culture Theory. Research in Consumer Behavior, Volume 11 (pp. 209-240), Oxford, UK, Elsevier.

DeYoung, R. (1986). Encouraging environmentally appropriate behavior: The role of intrinsic motivation. Journal of Environmental Systems, 15(4), 281-291.

Diener, E., Seligman, M. E. (2002). Very happy people. Psychological Science, 13(1), 81-84.

Dillon, W. R., Madden, T. J., Firtle, N. H. (1993). Research in a marketing environment. St. Louis: Times Mirror.

Dittmar, H., Pepper, L. (1994). To have is to be: Materialism and person perception in working-class and middle-class British adolescents. Journal of Economic Psychology, 15(2), 233-251.

Easterlin R. (1974). Does Economic Growth Improve the Human Lot? In: David, P.A. and Reder, M.W. (Ed.), Nations and Households in Economic Growth: Essays in Honor of Moses Abramovitz (pp. 89-125), New York, Academic Press.

Erdfelder, E., Faul, F., Buchner, A. (1996). Behavior Research Methods, Instruments, \& Computers, 28(1), 1-11.

Flurry, L. A., Swimberghe, K., \& Allen, J. (2021). Exposing the moderating impact of parentchild value congruence on the relationship between adolescents' materialism and subjective well-being. Journal of Business Research, 128, 290-302.

Fornell, C., Larcker, D.F. (1981). Evaluating structural equation models with unobservable variables and measurement error, Journal of Marketing Research, 18(1), 39-50.

Frank, R. H. (2008). Should public policy respond to positional externalities?. Journal of Public Economics, 92(8-9), 1777-1786.

Goldsmith, R. E., Clark, R. A. (2012). Materialism, status consumption, and consumer independence. Journal of Social Psychology, 152(1), 43-60.

Goldsmith, R. E., Flynn, L. R., Clark, R. A. (2011). Materialism and brand engagement as shopping motivations. Journal of Retailing and Consumer Services, 18(4), 278-284.

Gui, B., \& Stanca, L. (2010). Happiness and relational goods: well-being and interpersonal relations in the economic sphere. International Review of Economics, 57(2), 105-118. 
Hayes, A. F. (2012). PROCESS: A versatile computational tool for observed variable mediation, moderation, and conditional process modeling [White paper]. Retrieved from http://www.afhayes.com/public/process2012.pdf

Hayes, A. F. (2013). Introduction to Mediation, Moderation, and Conditional Process Analysis: A Regression-Based Approach. New York, NY: The Guilford Press.

Hayes, A. F., Matthes, J. (2009). Computational procedures for probing interactions in OLS and logistic regression: SPSS and SAS implementations. Behavior Research Methods, 41, 924-936.

Hirschman, E. C., Holbrook, M. B. (1982). Hedonic Consumption: Emerging Concepts, Methods and Propositions. Journal of Marketing, 46(3), 92-101.

Hu, M., Xiang, G., \& Zhong, S. (2021). The Burden of Social Connectedness: Do Escalating Gift Expenditures Make You Happy?. Journal of Happiness Studies, 1-19. https://doi.org/10.1007/s10902-020-00341-6

Huneke, M. E. (2005). The Face of the Un-Consumer: An Empirical Examination of the Practice of Voluntary Simplicity in the United States. Psychology \& Marketing, 22(7), 527550.

Iyer R, Muncy J. (2009). Purpose and object of anticonsumption. Journal of Business Research 62(2), 160-168.

Jaikumar, S., Singh, R., \& Sarin, A. (2018). 'I show off, so I am well off': Subjective economic well-being and conspicuous consumption in an emerging economy. Journal of Business Research, 86, 386-393.

Jaunky, V.C., Jeetoo, J., Rampersad, S. (2020). Happiness and Consumption in Mauritius: An Exploratory Study of Socio-Economic Dimensions, Basic Needs, Luxuries and Personality Traits. Journal of Happiness Studies, 21(7), 2377-2403.

Johnson, P. O., Fay, L. C. (1950). The Johnson-Neyman Technique, Its Theory and Application. Psychometrika, 15(4), 349-367.

Kasser, T. (2002). The high price of materialism. Cambridge, MA: MIT Press.

Kaus, W. (2013). Conspicuous consumption and "race": Evidence from South Africa. Journal of Development Economics, 100(1), 63-73.

Kline, R. B. (1998), Principles and Practice of Structural Equation Modeling, Guilford Press, New York, NY.

Lastovicka, J. L., Bettencourt, L. A., Hughner, R. S., Kuntze, R. J. (1999). Lifestyle of the tight and frugal: Theory and measurement. Journal of Consumer Research, 26(1), 85-98.

Layard, R. (1980). Human Satisfactions and Public Policy. Economic Journal, 90(360), $737-$ 750 . 
Lee, M. S. W., Ahn, C. S. Y. (2016). Anti-consumption, Materialism, and Consumer Wellbeing. Journal of Consumer Affairs, 50(1), 18-47.

Leigh, J. H., Gabel, T. G. (1992). Symbolic Interactionism: Its Effects on Consumer Behaviour and Implications for Marketing Strategy. Journal of Services Marketing, 6(3), 516.

Loureiro, S. M. C. (2017). Consumption and Well-Being: Collecting Experiences Rather Than Material Possessions. In: Li, E. Y. Advances in Marketing Customer Relationship Management, and e-Services Book Series. Hershey, PA: IGI Global.

Lyubomirsky, S., Lepper, H. S. (1999). A Measure of Subjective Happiness: preliminary reliability and construct validation. Social Indicators Research, 46(2), 137-155.

Malone, G. P., Pillow, D. R., Osman, A. (2012). The general belongingness scale (GBS): Assessing achieved belongingness. Personality and Individual Differences, 52(3), 311-316.

Mattick, R., Clarke, C. (1998). Development and Validation of Measure of Social Phobia Scrutiny Fear and Social Interaction Anxiety. Behavior Research and Therapy, 36(4), 455470 .

McFerran, B., Aquino, K., Tracy, J. L. (2014). Evidence for Two Facets of Pride in Consumption: Findings from Luxury Brands. Journal of Consumer Psychology, 24(4), 455471.

Mead, N., Baumeister, R., Stillman, T., Rawn, C. (2010). Social Exclusion Causes People to Spend and Consume Strategically in the Service of Affiliation. Journal of Consumer Research, 37(5), 902-919.

Meisenberg, G., Woodley, M. A. (2015). Gender Differences in Subjective Well-Being and Their Relationships with Gender Equality. Journal of Happiness Studies, 16(6), 1539-1555.

Myers, D. (2000). The funds, friends, and faith of happy people. American Psychologist, 55(1), 56-67.

Norris, J. I., Larsen, J. T. (2011). Wanting more than you have and its Consequences for Well-being. Journal of Happiness Studies, 12(5), 877-885.

O'Cass, A., McEwen, H. (2004). Exploring consumer status and conspicuous consumption. Journal of Consumer Behaviour, 4(1), 25-39.

O'Shaughnessy, J., O'Shaughnessy, N. J. (2002). Marketing, the consumer society and hedonism. European Journal of Marketing, 36(5), 524-547.

Pan, L., Pezzuti. T., Lu, W., Pechmann, C. (2019). Hyperopia and frugality: Different motivational drivers and yet similar effects on consumer spending, Journal of Business Research, 95, 347-356. 
Podsakoff, P.M., Mackenzie, S.B., Lee, J.Y.; Podsakoff, N.P. (2003). Common method biases in behavioral research: A critical review of the literature and recommended remedies. Journal of Applied Psychology, 88(5), 879-903.

Richins, M. L. (2004). The Material Values Scale: Measurement Properties and Development of a Short Form. Journal of Consumer Research, 31(1), 209-219.

Richins, M. L., Dawson, S. (1992). A Consumer Values Orientation for Materialism and its Measurement: Scale Development and Validation, Journal of Consumer Research, 19(3), 303-316.

Sahranç, Ü., Çelik, E., Turan, M. E. (2018). Mediating and Moderating Effects of Social Support in the Relationship Between Social Anxiety and Hope Levels in Children. Journal of Happiness Studies, 19(4), 1003-1019.

Schroeder, J. E., Dugal, S. S. (1995). Psychological Correlates of the Materialist Construct. Journal of Social Behavior and Personality, 10(1), 243-253.

Sharma, P. (2010). Country of origin effects in developed and emerging markets: exploring the contrasting roles of materialism and value consciousness. Journal of International Business Studies, 42(2), 1-22.

Shaw, J. W. (2002). Materialism, Psychological Well-Being, and Overall Quality of Life. Quality of Life Research, 11 (7), 661.

Sheth, J.N., Newman, B.I., Gross, B.L. (1991). Consumption Values and Market Choices: Theory and Applications, South-Western Publishing, Cincinnati, $\mathrm{OH}$.

Shukla, P. (2011). Impact of interpersonal influences, brand origin and brand image on luxury purchase intentions: measuring interfunctional interactions and a cross-national comparison. Journal of World Business, 46(2), 242-52.

Shukla, P. (2012). The influence of value perceptions on luxury purchase intentions in developed and emerging markets. International Marketing Review, 29(6), 574-596.

Siemsen, E., Roth, A., Oliveira, P. (2010). Common Method Bias in Regression Models with Linear, Quadratic, and Interaction Effects. Organizational Research Methods, 13(3), 456-476.

Sirgy, M. J., Lee, D.-J., Rahtz, D. (2007). Research on Consumer Well-Being (CWB): Overview of the Field and Introduction to the Special Issue. Journal of Macromarketing, 27(4), 341-349.

Sjåstad, H., Zhang, M., Masvie, A. E., \& Baumeister, R. (2021). Social exclusion reduces happiness by creating expectations of future rejection. Self and Identity, 20(1), 116-125.

Spiller, S. A., Fitzsimons, G. J., Lynch, J. G., McClelland, G. (2012). Spotlights, Floodlights, and the Magic Number Zero: Simple Effects Tests in Moderated Regression. Journal of Marketing Research, 50(2), 277-288. 
Stevenson, B., Wolfers, J. (2008). Economic growth and Happiness: Reassessing the Easterlin Paradox. NBER Working papers 14282, National Bureau of Economic Research, Inc.

Retrieved from http://ftp.iza.org/dp3654.pdf

Sullivan, L., Harnish, R. (1990). Body image: Differences in high and low self-monitoring males and females'. Journal of Research in Personality, 24(3), 291-302.

Tabachnick, B. G., L. S. Fidell (2001). Using Multivariate Statistics, 4th Edition, Allyn and Bacon, Needham Heights, MA.

Tanzer, J.R., Weyandt, L. (2020). Imaging Happiness: Meta Analysis and Review. Journal of Happiness Studies 21(7), 2693-2734.

Trigg, A. (2001). Veblen, Bourdieu, and conspicuous consumption. Journal of Economic Issues, 35(1), 99-115.

Veenhoven, R. (2003). Hedonism and Happiness. Journal of Happiness Studies, 4(4), 437457.

Venkatesh, A. (1994). India's Changing Consumer Economy: A Cultural Perspective. Advances in Consumer Research, 21, 323-328.

Vigneron, F., Johnson, L.W. (2004). Measuring perceptions of brand luxury. Journal of Brand Management, 11(6), 484-508.

Voss, K. E., Spangenberg, E. R., Grohmann, B. (2003). Measuring the Hedonic and Utilitarian Dimensions of Consumer Attitude. Journal of Marketing Research, 25(3), 310 320.

Waldinger, R. J., Schulz, M. S. (2010). What's Love Got To Do With It?: Social Functioning, Perceived Health, and Daily Happiness in Married Octogenarians. Psychology Aging, 25(2), 422-431.

Wang, H., Cheng, Z., \& Smyth, R. (2019). Consumption and happiness. The Journal of Development Studies, 55(1), 120-136.

Wang, L., Gu, D., Jiang J., Sun, Y. (2019). The Not-So-Dark Side of Materialism: Can Public Versus Private Contexts Make Materialists Less Eco-Unfriendly?, Frontiers in Psychology, 10:790, 1-10.

Wang, R., Liu, H., Jiang, J., Song, Y. (2017). Will materialism lead to happiness? A longitudinal analysis of the mediating role of psychological needs satisfaction. Personality and Individual Differences, 105, 312-317.

Warburton, D. M. (1996). The functions of pleasure: In D. M. Warburton and N. Sherwood (eds), Pleasure and Quality of life, Wiley: Chichester.

Warde, A. (1994). Consumption, identity-formation and uncertainty. Sociology, 28(4), 877898. 
Winkelmann, R. (2012). Conspicuous consumption and satisfaction. Journal of Economic Psychology, 33(1), 183-191.

Wong, N., Ahuvia, A. (1998). Personal taste and family face: Luxury consumption in Confucian and Western societies. Journal of Psychology and Marketing, 15(5), 423-441.

Xu, W., Jin, X. (2020). How social exclusion and temporal distance influence product choices: the role of coping strategies. Asia Pacific Journal of Marketing and Logistics, 33(2), 351-370.

\section{Appendix A - Measures in english and Portuguese}

\section{Subjective Happiness}

Lyubomirsky and Lepper (1999)

1. In general, I consider myself

not a very person a very happy person

2. Compared to most of my peers, I consider myself

less happy more happy

3. Some people are generally very happy. They enjoy life regardless of what is going on, getting the most out of everything. To what extent does this characterization describe you? not at all

a great deal

4. Some people are generally not very happy. Although they are not depressed, they never seem as happy as they might be. To what extent does this characterization describe you? not at all

a great deal

Portuguese

1. De modo geral, eu me considero...

uma pessoa não muito feliz

uma pessoa feliz

2. Comparado com a maioria das pessoas que conheço, eu me considero...

menos feliz

mais feliz

3. Normalmente, algumas pessoas são felizes. Elas curtem a vida independentemente do que esteja acontecendo, aproveitando o máximo de tudo. De que forma essa frase caracteriza você?

De forma alguma exatamente assim

4. Normalmente, algumas pessoas não são tão felizes. Embora elas não sejam depressivas, elas nunca parecem tão alegres quanto elas devem ser. De que forma essa frase caracteriza você?

De forma alguma

exatamente assim

\section{Social Anxiety - Social Interaction Anxiety Scale (SIAS)}

Mattick and Clarke (1998)

1. I get nervous if I have to speak with someone in authority (teacher, boss, etc.)

2. I have difficulty making eye-contact with others 
3. I become tense if I have to talk about myself or my feelings

4. I find difficulty mixing comfortably with the people I work with

5. I tense-up if I meet an acquaintance in the street

6. When mixing socially I am uncomfortable

7. I feel tense if I am alone with just one other person

8. I am at ease meeting people at parties, etc.

9. I have difficulty talking with other people

10. I find it easy to think of things to talk about.

11. I worry about expressing myself in case I appear awkward

12. I find it difficult to disagree with another's point of view

13. I have difficulty talking to attractive persons of the opposite sex

14. I find myself worrying that I won't know what to say in social situations

15. I am nervous mixing with people I don't know well

16. I feel I'll say something embarrassing when talking

17. When mixing in a group I find myself worrying I will be ignored

18. I am tense mixing in a group

19. I am unsure whether to greet someone I know only slightly

Portuguese

1. Fico nervoso em ter que falar com alguma pessoa em um nível mais alto que o meu (chefe no trabalho etc.)

2. Tenho dificuldade em manter contato olho no olho com outras pessoas

3. Fico tenso quando tenho que falar sobre mim ou meus sentimentos

4. Tenho dificuldade em me relacionar com as pessoas com quem trabalho.

5. Fico tenso quando me encontro com um conhecido na rua

6. Quando estou em grupos sociais eu não me sinto desconfortável

7. Sinto-me tenso quando estou sozinho com uma única pessoa em um ambiente

8. Tenho facilidade em falar com pessoas em festas, encontros etc.

9. Tenho dificuldade em falar com outras pessoas

10. Acho fácil pensar em coisas para iniciar uma conversa

11. Preocupo-me em parecer esquisito/estranho quando estou falando sobre mim

12. Tenho dificuldade em discordar com o ponto de vista de outras pessoas

13. Tenho dificuldade em falar com pessoas atraentes do sexo oposto

14. Fico me preocupando em não saber o que dizer em eventos sociais

15. Fico nervoso quando me socializo com pessoas que não conheço muito bem

16. Sinto que digo algo sem sentido quando falo

17. Preocupo-me em ser ignorado quando estou me socializando

18. Fico tenso quando me socializo

19. Sinto-me desconfortável em cumprimentar alguém que não conheço muito bem.

\section{Materialism}

Richins (2004)

1. It is important to me to have really nice things.

2. I would like to be rich enough to buy anything I want.

3. I would be happier if I could afford to buy more things.

4. It sometimes bothers me quite a bit that I cannot afford to buy all the things I want.

5. People place too much emphasis on material things.

6. It's really true that money can buy happiness. 
Portuguese

1. É importante para mim que possa ter coisas de bom gosto.

2. Gostaria de ser rico suficiente para comprar tudo que gostaria de ter.

3. Seria mais feliz se pudesse comprar mais coisas

4. Às vezes fico aborrecido quando não consigo comprar tudo que quero

5. As pessoas colocam muito foco em coisas materiais

6. É verdade que o dinheiro pode comprar felicidade

\section{Frugality}

Lastovicka et al. (1999)

1. If you take good care of your possessions, you will definitely save money in the long run

2. There are many things that are normally thrown away that are still quite useful

3. Making better use of my resources makes me feel good

4. If you can re-use an item you already have, there's no sense in buying something new

5 . I believe in being careful in how I spend my money

6. I discipline myself to get the most from my money

7. I am willing to wait on a purchase I want so that I can save money

8. There are things I resist buying today so I can save for tomorrow

Portuguese

1. Se você cuida bem de seus bens, com certeza você economizará dinheiro no longo prazo

2. Há muitas coisas que normalmente são jogadas fora, mas que ainda podem ser usadas

3. Fazer um melhor uso de meus bens me faz sentir bem

4. Se você pode reutilizar algo que você já possui, não faz sentido comprar algo novo

5. Sou cauteloso em como eu gasto meu dinheiro.

6. Eu me disciplino para tirar o máximo de proveito do meu dinheiro

7. Estou disposto a esperar comprar algo que quero para que possa economizar dinheiro

8. Há coisas que resisto a comprar hoje para que eu possa economizar para amanhã

\section{Hedonism}

Babin, Darden and Griffin (1994)

1. This shopping trip was truly a joy.

2. Compared to other things I could have done, the time spent shopping was truly enjoyable.

3. I continued shopping, not because I had to, but because I wanted to.

4. This shopping trip truly felt like a scape.

5. I enjoyed being immersed in exciting new products.

6. I enjoyed this shopping trip for its own sake, not just for items I may have purchased.

7. I continue to shop not because I had to, but because I wanted to.

8. I had a good time because I was able to act on the "spur of moment".

9. While shopping, I was able to forget my problems

10. While shopping, I felt a sense of adventure

11. I was able to do a lot of fantazing during this trip

Portuguese

1- Eu me divirto ao fazer compras 
2- Comparando com outras coisas que eu poderia fazer, o tempo gasto comprando é muito mais agradável

3- Eu faço compras porque quero e não por obrigação

4- Fazer as compras é uma forma de fuga/sair da rotina.

5- Gosto de participar de forma intensa na escolha e compra de novos produtos

6- Gosto de fazer compras só pelo fato de pensar em sair e não pelos produtos que compro

7- Faço compras não porque eu tenho que fazer, eu faço compras porque gosto.

8- Sair para comprar é uma forma de me motivar positivamente

9- Esqueço os meus problemas enquanto estou comprando

10- Quando saio para comprar sinto uma sensação de aventura

11- Fazer compras é uma forma de imaginar/fantasiar na vida.

\section{Social Acceptance (Normative)}

Bearden, Netemeyer and Teel (1989)

1. I rarely purchase the latest fashion styles until I am sure my friends approve of them.

2. It is important that others like the products and brands I buy.

3. When buying products, I generally purchase those brands that I think others will approve of.

4. If other people can see me using a product, I often purchase the brand they expect me to buy.

5. I like to know what brands and products make good impressions on others.

6. I achieve a sense of belonging by purchasing the same products and brands that others purchase. If I want to be like someone, I often try to buy the same brands that they buy. 7. I often identify with other people by purchasing the same products and brands they purchase.

\section{Portuguese}

1. Eu raramente compro os estilos mais recentes de moda até ter certeza de que meus amigos os aprovam.

2. É importante que outras pessoas gostem dos produtos e marcas que compro.

3. Ao comprar produtos, geralmente compro marcas que eu acho que outros vão aprovar.

4. Se outras pessoas podem me ver usando um produto, eu costumo comprar as marcas que eles esperam que eu compre.

5. Gosto de saber quais marcas e produtos causam boas impressões sobre as outras pessoas.

6. Tenho um sentimento de pertencimento social quando compro os mesmos produtos e marcas que outros compram. Se eu quiser ser como alguém, muitas vezes tento comprar as mesmas marcas que compram.

7. Muitas vezes eu me identifico com outras pessoas comprando os mesmos produtos e marcas que elas compram.

\section{Conspicuousness}

Shukla (2012)

\section{Conspicuous value}


1. Owning luxury goods indicates a symbol of achievement

2. Owning luxury goods indicates a symbol of wealth

3. Owning luxury goods indicates a symbol of prestige

4. Owning luxury goods attracts attention

Portuguese

1. Ter bens de luxo indica sucesso

2. Ter bens de luxo simboliza riqueza

3. Ter bens de luxo simboliza prestígio

4. Ter bens de luxo atrai atenção de outras pessoas 


\title{
SER OU NÃO SER FELIZ? EIS A QUESTÃO NO CONSUMO EM COMPORTAMENTOS SOCIAIS
}

\author{
Marcio Mota \\ Doutor em Administração \\ Universidade Estadual do Ceará - UECE \\ Fundação Getúlio Vargas - Escola de Administração do Estado de São Paulo FGV- EAESP \\ Fortaleza, Ceará - Brasil \\ marcio@marciomota.com \\ iD Delane Botelho \\ Doutor em Administração \\ Fundação Getúlio Vargas - Escola de Administração do Estado de São Paulo FGV- EAESP \\ São Paulo, São Paulo - Brasil \\ delane.botelho@fgv.br
}

Objetivo do estudo: Examinar e avaliar as funções moderadoras dos comportamentos sociais e do consumo na felicidade.

Metodologia/abordagem: Foi realizada uma pesquisa do tipo survey com 197 consumidores reais. Foram utilizadas, para as análises dos dados, análise fatorial confirmatória e modelo de regressão linear com moderação incluindo a técnica de Johnson-Neyman.

Principais resultados: $\mathrm{O}$ hedonismo amplifica a relação positiva entre felicidade e frugalidade; a ansiedade social amplifica a relação negativa entre felicidade e materialismo; a conspicuidade enfraquece a relação positiva entre felicidade e aceitação social.

Contribuições teóricas: $\mathrm{O}$ estudo adiciona à literatura de felicidade, sob a perspectiva de um país emergente, a elucidação dos papéis moderadores da ansiedade social, hedonismo e conspicuidade no relacionamento entre materialismo, aceitação social, frugalidade e felicidade, os quais ainda há inconsistências na academia.

Relevância/originalidade: Até o presente momento, não há pesquisas sobre os efeitos simultâneos da felicidade no consumo e nos comportamentos sociais. O estudo testou os papéis moderadores da ansiedade social, hedonismo e conspicuidade na relação entre consumo, comportamentos sociais e felicidade.

Implicações para a gestão ou sociais: As empresas podem garantir que os consumidores reajam a diferentes níveis desses comportamentos sociais, pois, enquanto consomem marcas ou produtos, podem, ao mesmo tempo, (1) realizar esforços para criar laços sociais com os envolvidos; (2) permitir que os consumidores experienciem felicidade e (3) atrair novos clientes.

Palavras-chave: Felicidade. Hedonismo. Ligações sociais. Conspicuidade. Frugalidade. Materialismo.

\section{Como citar}

American Psychological Association (APA)

Mota, M., \& Botelho, D. (2021, jul./set.). Ser ou não ser feliz? eis a questão no consumo em comportamentos sociais. Revista Brasileira de Marketing - ReMarK, 20(3), 446-480. https://doi.org/10.5585/remark.v20i3.18367. 


\section{Introdução}

A felicidade tem sido o objetivo da vida do ser humano, embora seja um assunto complexo. A maioria das pessoas toma decisões todos os dias para alcançar esse objetivo universal. A filosofia da Grécia Antiga trouxe os primeiros entendimentos sobre a felicidade, mas apenas a biologia, a filosofia e a psicologia na modernidade começaram a analisar a consistência dessa construção. Sócrates propôs o "como devo viver?", pergunta de quase 2.500 anos, e os filósofos modernos tentam responder a perguntas como "como viver faz as pessoas felizes?" e "o que nos faz felizes?"

Pesquisas sobre a felicidade nas ciências sociais inicaram apenas na década de 1970, quando Easterlin (1974) propôs o Paradoxo de Easterlin ou Paradoxo da Felicidade, que afirma que, embora uma renda mais alta possa levar a uma maior felicidade entre indivíduos, um maior crescimento da renda ao longo do tempo não está associado a níveis mais elevados de felicidade. Por exemplo, países com taxas de crescimento relativamente altas do PIB per capita não apresentaram aumentos correspondentes em felicidade.

A felicidade é um aspecto multidimensional da vida humana (Bögenhold \& Naz, 2018), que pode ser explicada pelos seguintes mecanismos hedônicos, aspiracionais e de discrepância posicional: i) a esteira hedônica refere-se à ideia de que felicidade ou bem-estar podem permanecer inalterados, mesmo por maiores realizações materiais, devido à rápida adaptação; ii) a esteira da satisfação se refere à ideia de que a felicidade não pode aumentar juntamente com a renda se as aspirações aumentarem simultaneamente; e iii) a esteira posicional se refere à ideia de que a utilidade depende do nível de consumo relativo, ao invés de valores absolutos e, nesse caso, a felicidade pode não ser afetada por um aumento na renda de alguém se a renda de outras pessoas em seu grupo de referência também aumenta (Gui \& Stanca, 2010).

Avaliações de pesquisas sobre felicidade (Sjåstad, 2021) concluíram que fatores como renda e saúde são fortes preditores de felicidade apenas em aspectos subjetivos, mas a conexão social se destaca como um fator objetivo que afeta a felicidade. No entanto, existem resultados inconsistentes na literatura que pretendemos esclarecer neste estudo. Em primeiro lugar, faz sentido que ser socialmente aceito leva a felicidade, mas estudos experimentais mostram que a rejeição social não consegue evidenciar uma relação negativa entre rejeição social e autoestima, que é um indicador da felicidade (Blackhart et al., 2009; Sjåstad, 2021).

Em segundo lugar, o uso de consumo conspícuo como um instrumento para sinalizar status relativo tem demonstrado fortalecer a conexão social (Hu et al., 2021). Por conseguinte, pode-se fortalecer o bem-estar e a felicidade do consumidor. Por exemplo, Jaikumar, Singh e 
Sarin (2018) descobriram que níveis mais elevados de consumo conspícuo estão associados a percepções aumentadas de bem-estar econômico subjetivo, ou seja, este efeito é ainda mais evidente entre as famílias na base da pirâmide. Portanto, o consumo conspícuo, como consumo de joias, pode refletir a posição social de uma pessoa em relação a um grupo de referência, o que pode aumentar a felicidade individual ao aumentar o status social (Wang et al., 2019). No entanto, Frank (2008) argumenta que o aumento do consumo por pessoas que têm renda alta tem um efeito sobre o consumo conspícuo dos indivíduos nas posições mais baixas da distribuição de renda, de modo que a desigualdade aumenta o esforço desses indivíduos para manter a posição relativa aparente por meio do consumo conspícuo, diminuindo sua felicidade.

Há pesquisas que fornecem evidências que o materialismo, característico daqueles que buscam a felicidade por objetivos externos como dinheiro, status e aparência, pode impedir a satisfação de necessidades psicológicas, minando a felicidade pessoal (Wang et al., 2017). No entanto, há evidências conflitantes nessa direção. Por exemplo, quando os adolescentes priorizam o materialismo como um valor pessoal alinhado com os valores materialistas de seus pais, os adolescentes relatam um maior bem-estar subjetivo, o que implica que o materialismo em si não leva necessariamente à infelicidade (vide Flurry et al., 2021 para mais exemplos)

Pouco se sabe sobre a relação entre felicidade, consumo e comportamentos sociais (Jaunky et al., 2020). O presente estudo acrescenta um melhor esclarecimento sobre essas questões da perspectiva de um país emegente à literatura sobre felicidade. Alguns pesquisadores começaram a apresentar desenvolvimentos interessantes sobre essa questão e pretendemos avançar em aspectos substanciais à área do marketing. Tanzer e Weyandt (2020) concluíram que a felicidade se encontra dentro de um contexto comportamental, que pode estar relacionado a outras condutas e vínculos sociais. Alguns estudos estabeleceram relações entre felicidade e ansiedade social (Schroeder \& Dugal, 1995; Mattick \& Clarke, 1998), aceitação social (Schroeder \& Dugal, 1995) e frugalidade (Lastovicka et al., 1999).

Não foram encontrados estudos sobre os efeitos simultâneos da felicidade no consumo e nos comportamentos sociais. Audette et al. (2018) sugerem que pesquisadores sobre felicidade devem expandir a pesquisa em determinantes que podem incluir fatores sociais. O tema ainda é incipiente e, em consonância com esses autores, precisaremos avançar em estudos empíricos e experimentais frente a esse estudo interdisciplinar da felicidade e de como o consumo e os comportamentos sociais se relacionam. O objetivo deste artigo é examinar e avaliar os papéis moderadores dos comportamentos sociais e do consumo na felicidade. Especificamente, testamos os papéis moderadores da ansiedade social, hedonismo e conspicuidade na relação 
entre materialismo, aceitação social e felicidade, que ainda apresentam inconsistências na literatura.

O estudo se encontra organizado em etapas, onde a primeira parte trata da revisão da literatura sobre felicidade, materialismo, hedonismo, conspicuidade, ansiedade social, frugalidade e aceitação social. A segunda parte trata da metodologia, seguido pelos resultados e sua discussão. Por fim, apresentamos as considerações finais, com implicações, limitações e orientações para pesquisas futuras.

\section{Revisão da literatura e desenvolvimento de hipóteses}

Os laços sociais são extremamente importantes para a felicidade (Diener \& Seligman, 2002), pois pessoas mais felizes têm boas conexões sociais e passam a maior parte do tempo se socializando, enquanto que aqueles que não estabelecem relacionamentos são considerados socialmente ansiosos e, consequentemente, mais infelizes (Myers, 2000). A aceitação social também está relacionada a vínculos de como as pessoas são julgadas positiva ou negativamente pelos outros em padrões sociais (Baumeister \& Leary, 1995).

Em consonância com isso, se a pessoa se orienta por objetivos extrínsecos, a conspicuidade reflete no status e na posição social por conta da aprovação dos outros (Kaus, 2013). Enquanto pessoas materialistas compram produtos para serem admiradas e expressarem relações sociais e aprovação (Goldsmith \& Clark, 2012), o hedonismo torna as pessoas mais sociáveis (Veenhoven, 2003). Os frugais estão mais relacionados aos objetivos intrínsecos e estão menos preocupados com laços sociais (Corral-Verdugo et al., 2011).

Waldinger e Schulz (2010) pesquisaram o funcionamento social e a felicidade durante décadas, incluindo a quantidade e a qualidade das conexões interpessoais e descobriram que bons e próximos relacionamentos mantêm pessoas mais felizes. Na verdade, a felicidade é possibilitada quando somos qualificados para avaliar nossos laços sociais. Portanto, é evidente que fontes importantes de felicidade são os comportamentos sociais e os relacionamentos. Os indivíduos que têm dificuldade em estabelecer relacionamentos sociais podem ser afetados, apesar do desejo de fazê-lo e de levarem em consideração as opiniões de outras pessoas em suas relações sociais. Portanto, é considerado crítico compreender a relação entre os comportamentos sociais que encorajam ou prejudicam as relações sociais as quais proporcionam felicidade.

Waldinger e Schulz (2010) pesquisaram o funcionamento social e a felicidade durante décadas, incluindo quantidade e qualidade das conexões interpessoais, e descobriram que bons 
e próximos relacionamentos mantêm pessoas mais felizes. Na verdade, a felicidade é possibilitada quando somos hábeis em avaliar nosos laços sociais, de modo que fontes importantes de felicidade incluem comportamentos sociais e relacionamentos. É considerado crítico compreender a relação entre os comportamentos sociais que encorajam eu e que prejudicam as relações sociais que produzem felicidade.

\subsection{Felicidade, materialismo e ansiedade social}

O aumento do poder de compra do consumidor, a disponibilidade de produtos de consumo e o aumento do produto interno bruto (PIB) per capita levaram a uma economia mais dependente da inovação contínua. No entanto, o Paradoxo da Felicidade (Easterlin, 1974) reavaliado por Stevenson e Wolfers (2008) indica que mesmo com o aumento do PIB, as pessoas não mudaram seus níveis de felicidade.

Norris e Larsen (2011) e Kasser (2002) identificaram que a felicidade é afetada negativamente pelos consumidores materialistas quando estes querem mais, ou seja, quanto mais temos, menos felizes somos. Richins e Dawson (1992) descobriram que altos níveis de querer estão relacionados aos materialistas, e estes relataram menor evidência de satisfação. Eles também verificaram que os bens materiais não são uma fonte de felicidade. Além disso, a infelicidade está positivamente relacionada às posses materiais (Burroughs \& Rindfleisch, 2002) da mesma forma que Costley et al. (2007) afirmam que o materialismo não aumenta a felicidade. Algumas razões para esta relação negativa são: (i) a falta de controle que os materialistas têm com o consumo excessivo é visto como uma fuga (Lee \& Ahn, 2016); e (ii) a permissão para que esse consumo desempenhe um papel fundamental em suas vidas (Sirgy et al., 2007).

O materialismo é uma forma dos bens assumirem um papel importante na vida. Goldsmith e Clark (2012) argumentam que os materialistas desconhecem a quantidade de dinheiro que pagam por um bem devido ao alto nível de satisfação que podem ter ao adquirir um produto novo. Esses autores acreditam que esse tipo de consumidor compra produtos para ter respostas sociais, ou seja, outras pessoas podem admirá-los pelo alto padrão de qualidade que possuem. Kasser (2002) descreve que esses consumidores apresentam baixos níveis de autoestima. Na verdade, essa é a razão pela qual compram certos produtos para preencher uma lacuna sentimental. Da mesma forma, Dittmar e Pepper (1994) definem o materialismo como o comportamento pessoal e social de um indivíduo e a evidência de que os materialistas usam 
produtos para expressar sua personalidade, relações sociais, incluindo aceitação social e status (Goldsmith et al., 2011).

O reconhecimento de comportamentos sociais na sociedade de consumo está presente em nosso cotidiano. Por exemplo, indivíduos com níveis mais elevados de materialismo são propensos a se comportar de maneira diferente quando se encontram em público (Wang et al., 2019). Existe uma ansiedade existencial criada para o consumo e uma sensação de falta de coisas que não podemos ter ou pagar (Baumann, 2007). Warde (1994) apresentou o conceito de que as escolhas de consumo podem ser causadoras de ansiedade e as estratégias de marketing podem reduzir esse comportamento. Portanto, a ansiedade deve ser considerada um estado emocional com o qual devemos trabalhar devido a esse modo de ser da condição humana.

Para esclarecer a ansiedade social, a Associação Psiquiátrica Americana (1980) iniciou o desenvolvimento de escalas psicométricas na década de 1980, preocupando-se com a avaliação social das pessoas. Buss (1980) define ansiedade social como uma reação comportamental por preocupações com a forma de como os indivíduos são percebidos e avaliados pelos outros, ou seja, um tipo de ansiedade que inclui uma perspectiva de avaliação interpessoal em uma situação social. Ademais, isso pode ser sentido por pessoas que se deparam com novas situações, de tal modo que pode provocar o afastamento social (Sahranç et al., 2018).

O materialismo e a ansiedade social podem oferecer percepções úteis aos pesquisadores e profissionais de marketing e pode nos levar a explorar as possíveis consequências. Os materialistas têm menos autoestima (Belk, 1985) e "a ansiedade social implica em preocupação com a avaliação social" (Schroeder \& Dugal, 1995, p. 245). Como consequência, as pessoas preocupadas com a percepção dos outros tendem a ser mais materialistas.

Assim, construímos nossa primeira hipótese, da seguinte forma:

\section{(H1) a ansiedade social amplifica a relação negativa entre felicidade e materialismo.}

\subsection{Felicidade, frugalidade e hedonismo}

Os consumidores pós-modernos estão envolvidos com o materialismo e buscam demonstrar seus sentimentos e expressões sociais por meio de marcas e produtos. $\mathrm{O}$ anticonsumo centra-se num forte contraste com o materialismo e surge das motivações contra o consumo (Loureiro, 2017). De acordo com o que foi mencionado na seção anterior, as pessoas tendem a acreditar que suas posses as levarão a realizações e sucesso, o que é o oposto. Por exemplo, os materialistas tendem a se comparar a pessoas ricas e são mais infelizes devido ao seu desejo voraz de consumo (Shaw, 2002). Portanto, se a busca de bens não traz felicidade, e 
se os materialistas, cheios de forte desejo de consumo, podem levar a uma relação negativa de felicidade, os indivíduos que defendem o anticonsumo são mais felizes? Para diminuir esses efeitos negativos, o anticonsumo surge como uma forma de adaptação ao atual estilo de vida pós-moderno.

Indivíduos anticonsumistas estão mais preocupados com os problemas que a sociedade e o meio ambiente podem provocar com o consumo excessivo (Belk, 1988, Iyer \& Muncy, 2009). Além disso, eles também acreditam em um estilo de vida simples, sem consumo excessivo, e esse modo de vida os leva a objetivos intrínsecos com menos estresse e autorrealização (Huneke, 2002). Dessa forma, a frugalidade também é considerada um tipo de anticonsumo.

Em consonância com essa ideia, a frugalidade é uma forma voluntária pela qual um indivíduo adota um estilo de vida simples consumindo apenas o que realmente precisa. Os frugais evitam o desperdício e tendem a controlar as coisas que possuem de forma sustentável e responsável (DeYoung, 1986), gastando sabiamente como uma forma de atingir objetivos de longo prazo. Ressalte-se que essa abordagem do consumo está associada a aspectos sociais. Lastovicka et al. (1999) argumentam que a frugalidade é um construto útil para entender os comportamentos da experiência do consumidor e os consumidores frugais se distinguem como disciplinadores. Da mesma forma, "consumidores frugais evitam comprar bens de consumo com preços mais altos quando há produtos substitutos com preços mais baixos" (Pan et al., 2019, p.347). Assim, a frugalidade é um atributo do estilo de vida de pessoas que economizam mais dinheiro do que gastam (Bove et al., 2009).

Devido aos comportamentos frugais levarem à paz espiritual e social (Bouckaert, 2008), acreditamos que também podem levar à felicidade. Similarmente podemos supor que, desde que a frugalidade também esteja positivamente ligada ao anticonsumo, que é negativamente correlacionado ao materialismo, da mesma forma, consideramos que existe uma relação positiva entre indivíduos frugais e felicidade. Por fim, também entendemos que existe uma relação positiva entre os comportamentos frugais e hedônicos, uma vez que Baumeister et al. (1994) descobriram que quando indivíduos frugais se sentem culpados ao comprar produtos de luxo, eles equilibram esse comportamento envolvendo-se com sensações hedônicas.

A etimologia da palavra hedonismo deriva da palavra grega hedone, que significa gozo e prazer, e se relaciona com uma gratificação para si. Da mesma forma, é visto como uma busca de prazer que aspira experiências de qualidade conduzidas por padrões de sentimentos 
(O'Shaughnessy \& O'Shaughnessy, 2002). Campbell (1987) afirma que pesquisadores e profissionais de marketing devem entender como os consumidores geram esses sentimentos.

Os estudos seminais sobre o consumo hedônico foram desenvolvidos pela primeira vez por Hirschman e Holbrook (1982). O hedonismo é uma importante característica do consumidor (Chitturi et al., 2007) e se refere às facetas do comportamento do consumidor relacionadas aos múltiplos aspectos sensoriais que evocam uma variedade de significados associados a sabores, sons, cheiros, impressões táteis e imagens (Hirschman \& Holbrook, 1982). Assim, o hedônico resulta de "sensações derivadas da experiência de uso de um produto" (Voss et al., 2003, p. 310). O consumidor hedônico é aquele que busca despertar bons sentimentos por meio da utilidade percebida na compra de um produto sem se preocupar com as normas impostas por um grupo ao qual o indivíduo pertence (Goldsmith \& Clark, 2012).

Além disso, os méritos do hedonismo são a busca do prazer e seus benefícios levam a: (i) reduzir o estresse (Warburton 1996); (ii) contribuir para a felicidade pelo equilíbrio de sentimentos agradáveis; e (iii) tornar as pessoas mais sociáveis (Veenhoven , 2003). Portanto, o último benefício fortalece os laços sociais e conduz a situações mais prazerosas no futuro. Portanto, quem procura o prazer pode ativar níveis mais elevados de felicidade.

Essa nossa segunda hipótese é baseada na relação entre felicidade, frugalidade e hedonismo da seguinte maneira:

\section{(H2) o hedonismo modera positivamente a relação positiva entre felicidade e frugalidade.}

\subsection{Felicidade, consumo conspícuo e aceitação social}

A área da felicidade tem sido relativamente negligenciada pelos pesquisadores e, ainda assim, entendemos as razões de como o consumo conspícuo e a aceitação social ainda não são esclarecedores à academia. As externalidades de consumo são fundamentais para entender o que motiva alguém a adquirir bens e serviços. Winkelmann (2012) atribui que o consumo próprio pode ser influenciado pelo consumo dos outros com base na conspicuidade ou pela aceitação social e status social do consumo (Venkatesh, 1994).

Arslan (2018) define aceitação social como a percepção do indivíduo de ser incluído e valorizado na sociedade e incentivado a fazer parte do ambiente social. Além disso, Malone et al. (2012) argumentam que a aceitação social é possivelmente associada à felicidade para que emoções positivas possam ser evocadas, como contentamento, alegria e exaltação.

Essas emoções e comportamentos sociais parecem ser afetados pelas aspirações dos países emergentes sob a pressão das tendências de consumo (Shukla, 2012), gastando mais em 
bens visíveis para serem socialmente aceitos entre vizinhos ou parentes (Venkatesh, 1994, Winkelmann, 2012). Da mesma forma, essa taxa de consumo possivelmente não aumenta o nível de satisfação, bem-estar ou felicidade. Por exemplo, Layard (1980) afirma que o resultado da ação motivada pelo status quando os indivíduos fazem sacrifícios para melhorar sua posição social é a insatisfação. Além disso, as pessoas que adquirem mais esses produtos tendem a ficar mais infelizes e menos satisfeitas com suas vidas (Winkelmann, 2012).

O consumo conspícuo é definido pelo ato de comprar uma variedade de serviços e bens que muitas vezes são desnecessários e caros no intuito de chamar a atenção de alguém (Shukla, 2011) e é também considerado o comportamento social que mostra riqueza pelo consumo luxuoso de bens e serviços (Trigg, 2001). Vigneron e Johnson (2004) afirmam que a conspicuidade desempenha um papel significativo nas preferências do consumidor. Na verdade, os bens de luxo influenciam os consumidores em promover a aceitação social (Shukla, 2011). Além disso, uma forma de identificar comportamentos conspícuos de consumo é estudando motivos de orientação social (Sharma, 2010). O'Cass e McEwen (2004, p. 26) sugerem que "tendências de consumo conspícuo dos consumidores são importantes na criação de relacionamentos entre consumidores que possuem tais características e marcas que geram status" e "o desejo do consumidor por bens conspícuos ainda é amplamente determinado por suas redes sociais "(p. 28). Portanto, o consumo conspícuo também pode ser visto como um individualismo anti-social.

Se alguém deseja ser aprovado socialmente, essa pessoa deve se envolver em uma situação pessoal composta de posses em um envolvimento significativamente visível e personalizável (Richins \& Dawson, 1992; Dittmar \& Pepper, 1994). As normas sociais influenciam os comportamentos de compra e estão sujeitas às pressões da sociedade sob a perspectiva de status e prestígio (Belk, 1988). Sheth et al. (1991) argumentam que existem associações entre o simbolismo e a imagem de alguém com grupos socioeconômicos e demográficos, de modo que os consumidores tendem a ser afetados pelo prestígio social e status ao adquirir e consumir bens e serviços. Além disso, os consumidores também usam os bens para confirmar suas relações sociais e para afirmar seus comportamentos pessoais (Dittmar \& Pepper, 1994). Os bens podem significar associação a um grupo, podem atuar como a imagem que os consumidores desejam expressar aos outros e podem ser uma forma de adquirir status social (Goldsmith \& Clark, 2012). Assim, o consumo conspícuo modera as relações sociais a fim de levar a aceitação social pela conspicuidade. 
Essa lógica também é explorada pela maneira como os consumidores são suscetíveis às influências normativas que as decisões de compra dos indivíduos precisam para se adequar à imagem de alguém com produtos e marcas às expectativas dos outros (Bearden et al., 1989). Além disso, os consumidores compram um produto específico pelo que ele representa para si e para os demais com os quais desejam se afiliar (Leigh \& Gabel, 1992). Parece que adquirir esse produto específico é um pré-requisito para ser aceito pelo grupo social desejado.

Consequentemente, quando não conseguem obter uma impressão desejável, ocorre a desaprovação social. Xu e Jin (2020) argumentam que a exclusão social tem um papel negativo na necessidade humana de pertencer e, para evitá-la, sacrificam sua felicidade em prol do bemestar social (Mead et al., 2010). No entanto, há uma lacuna em identificar até que ponto o sacrifício vale a pena, e o uso de moderadores é benéfico para descobrir isso. Xu e Jin (2020) também investigam que as pessoas socialmente excluídas gastam mais para se afiliarem coletivamente novamente. Essa conexão revela o quanto um indivíduo provavelmente terá quando for ameaçado pela rejeição social, incluindo o consumo ostensivo.

Em consonância com essa ideia, O'Cass e McEwen (2004) enfatizam que a conspicuidade é crítica quando os indivíduos desejam ter aceitação e reconhecimento social. O consumo conspícuo fornece aprovação ou desaprovação social, e marcas podem permitir vínculos com grupos de referência (Sullivan \& Harnish, 1990). Na verdade, Wong e Ahuvia (1998) afirmam que a influência das redes sociais estabelece os desejos dos indivíduos pelo consumo conspícuo.

Nossa última hipótese baseia-se na relação entre felicidade, aceitação social e conspicuidade e, após revisitarmos a literatura, assumimos a seguinte hipótese:

(H3) a conspicuidade modera negativamente a relação positiva entre felicidade e aceitação social.

\section{Metodologia}

\subsection{Amostragem e coleta de dados}

A amostra foi baseada em 197 consumidores reais em uma capital do Brasil com mais de 2,5 milhões de habitantes. Portando uma prancheta contendo os questionários, os entrevistadores interceptaram, aleatoriamente, pessoas que circulavam em shoppings, ruas e supermercados e os convidaram a participar de um estudo de pesquisa que pretendia avaliar seus comportamentos como consumidores. Usamos uma amostragem probabilística sistemática escolhendo um a cada 10 entrevistados presentes nesses locais. Os locais foram escolhidos com 
base na distribuição demográfica do Instituto Brasileiro de Geografia e Estatística, órgão governamental responsável pela coleta oficial de dados estatísticos, a fim de mitigar o viés de amostragem. O tempo médio de preenchimento do questionário foi de aproximadamente 13 minutos.

A fim de verificar se nossos resultados foram significativos devido ao poder estatístico, executamos uma análise de poder usando o software GPower (Erdfelder et al., 1996) com os seguintes parâmetros: tamanho do efeito $\mathrm{f}^{2}=0.15, \beta /($ proporção do $\alpha)=4$; com 197 respondentes e o número de preditores de cada modelo, obtivemos um parâmetro de não centralidade $\lambda=29,55, \mathrm{~F}$ crítico $=4,35$, erro da probabilidade do $\alpha=0,005$, erro de probabilidade do $\beta=0,021$ e potência (1- $\beta$ ) definida em 0,978 , bicaudal. Isso mostrou que há uma grande chance de rejeitar a hipótese nula com um total de 197 respondentes.

\subsection{Instrumento de Pesquisa e Escalas}

O instrumento de pesquisa (vide Apêndice A) foi elaborado para medir sete variáveis: felicidade, materialismo, ansiedade social, hedonismo, frugalidade, conspicuidade e aceitação social. O estudo foi baseado em várias escalas já validadas, as quais foram adaptadas e traduzidas para a língua portuguesa. É importante ressaltar que a versão em português desses itens foi adaptada e traduzida por um profissional com doutorado em linguística (inglês e português). Para validade de conteúdo, as escalas foram testadas e validadas por três especialistas em marketing e um professor sênior de marketing (Dillon et al., 1993). Por fim, para a validade de face, foi realizado um pré-teste do instrumento de pesquisa com 20 pessoas. O instrumento de pesquisa não exigiu alterações após o processo de triagem do pré-teste.

Para medir a felicidade, usamos a escala de Felicidade Subjetiva de quatro itens (Lyubomirsky \& Lepper, 1999). A ansiedade social foi medida pedindo aos participantes que indicassem com que intensidade eles se relacionam com sua ansiedade (Mattick \& Clarke, 1998). O materialismo incluiu a escala de materialismo de seis itens proposta por Richins (2004) e a escala de frugalidade de oito itens baseada em Lastovicka et al. (1999).

Para medir o hedonismo, usamos a escala de onze itens desenvolvida por Babin et al. (1994), e para aceitação social, usamos a escala normativa de suscetibilidade do consumidor à influência interpessoal de sete itens de Bearden et al. (1989). A última escala que usamos no estudo foi sobre conspicuidade com base na escala de valor conspícuo de Shukla (2012). 


\subsection{Análise de dados}

A pesquisa foi dividida em três blocos para cada hipótese (H1 a H3) e em duas etapas para cada bloco. Na primeira etapa, uma análise fatorial confirmatória foi usada para testar o modelo de mensuração. Usamos o IBM AMOS para realizar esta etapa a fim de compreender a natureza multidimensional de cada construto. Também avaliamos as validades convergente e discriminante de acordo com os critérios de Anderson e Gerbing (1988). Na segunda etapa, usamos o Modelo 1 do módulo Process (Hayes, 2013), usando bootstrap com 10.000 reamostragens para avaliar se as diferenças, direções e interações entre as variáveis foram estatisticamente significativas, incluindo a técnica de Johnson-Neyman que mostra onde o efeito é significativo na moderação (Johnson \& Fay, 1950).

Esta técnica é extremamente útil em moderação devido à possibilidade de identificar as regiões de significância do efeito de $\mathrm{X}$ sobre $\mathrm{Y}$ ao longo do continuum da dimensão medida por M (Hayes \& Matthes, 2009). Essa técnica fornece uma visão mais ampla das áreas onde a moderação tem um efeito importante, e os intervalos de confiança com $95 \%$ ao longo do eixo de regressão simples, que define a(s) região(ões) de importância, as quais são usadas nesta técnica. Portanto, esta técnica "identifica o valor ou valores dentro da faixa de medição da variável moderadora onde o efeito condicional de $\mathrm{X}$ encontra-se estatisticamente significante a um nível significante de $\alpha "$ (Hayes, 2012, p. 16).

\subsection{Estatística Descritiva}

Dos 197 respondentes, 97 (49,2\%) eram do sexo masculino e 100 (50,8\%) do feminino. As idades dos respondentes variaram de 18 a mais de 52, $94(47,7 \%)$ tinham entre 18 e 25 anos, $47(23,9 \%)$ tinham entre 26 e 34 anos, 39 (19,8\%) tinham entre 35 e 43 anos, 6 (3\%) tinham entre 44 e 52 anos e, por fim, 11 (5,6\%) tinham mais de 52 anos. Também perguntamos sobre sua renda familiar anual. Dos 197 entrevistados, 29 (14,7\%) ganhavam menos de US \$ 7.621,00 por ano, $87(44,2 \%)$ entre US \$ 7.622,00 e US \$22.864,00, 34 (17,3\%) entre US \$22.685,00 e US \$34.296,00 e, finalmente, 47 (23,9\%) ganhavam mais de US \$34.296,00 por ano.

\section{Resultados}

Antes de testar as hipóteses e suas interpretações, testamos as variáveis quanto à multicolinearidade. As correlações bivariadas entre as variáveis foram todas inferiores a 0,80 e foram estatisticamente significantes. A maior correlação foi entre ansiedade social e materialismo com 0,76 . Também executamos um teste de correlação canônica entre todas as 
variáveis e o teste $\mathrm{F}$ foi igual a 75,345 com sete graus de liberdade, correlação igual a 0,758 , Lambda de Wilks $=0,264$ e $p<0,001$. Esses resultados sugerem que a multicolinearidade não foi um problema em nossos dados (Tabachnick \& Fidell, 2001). As estatísticas descritivas e correlações bivariadas para todas as variáveis compostas são apresentadas na Tabela 1.

Tabela 1 - Estatístca descritiva e correlações bivariadas

\begin{tabular}{llllllllll}
\hline Variáveis & Média & $\begin{array}{l}\text { Desvio } \\
\text { Padrão }\end{array}$ & $\mathbf{1}$ & $\mathbf{2}$ & $\mathbf{3}$ & $\mathbf{4}$ & $\mathbf{5}$ & $\mathbf{6}$ & $\mathbf{7}$ \\
\hline 1. Felicidade & 4,48 & 1,23 & $(0,86)$ & & & & & \\
2. Materialismo & 3,96 & 1,77 & $-0,39^{* * *}$ & $(0,77)$ & & & & & \\
3. Ansiedade Social & 3,68 & 1,60 & $-0,40^{* *}$ & $0,76^{* *}$ & $(0,86)$ & & & & \\
4. Frugalidade & 4,51 & 1,87 & $0,65^{* *}$ & $-0,25^{* *}$ & $0,23^{* *}$ & $(0,89)$ & & & \\
5. Hedonismo & 5,17 & 1,18 & $0,45^{* *}$ & $-0,18^{*}$ & $0,20^{* *}$ & $0,05^{\#}$ & $(0,92)$ & & \\
6. Conspicuidade & 2,70 & 1,44 & $-0,37^{* *}$ & $0,11^{\#}$ & $0,10^{\#}$ & $0,31^{* *}$ & $0,18^{* *}$ & $(0,88)$ & \\
7. Aceitação Social & 3,76 & 1,34 & $0,27^{* *}$ & $-0,04^{\#}$ & $-0,61^{\#}$ & $0,17^{*}$ & $0,15^{*}$ & $0,002^{\#}$ & $(0,92)$ \\
\hline
\end{tabular}

Nota: Números entre parênteses são os alfas de Cronbach.

**Correlação significante em 0,01 (bicaudal). * Correlação significante em 0,05 (bicaudal). \#Correlação não significante.

Fonte: Elaborado pelos autores.

A qualidade do modelo em termos de confiabilidade, validade convergente $\mathrm{e}$ discriminante são examinadas nesta seção. Estes foram medidos examinando os valores de confiabilidade composta (CR) para analisar a confiabilidade (CR>0,70) e confiabilidade máxima $(\operatorname{Max}(\mathrm{H})(\operatorname{Max}(\mathrm{H})>\mathrm{CR})$; valores de variância média extraída (AVE) para analisar a validade convergente (AVE>0,5 e CR> AVE); e variância quadrada compartilhada máxima (MSV), variância quadrada compartilhada média (ASV) e raiz quadrada da AVE (SQRT AVE) para verificar a validade discriminante (MSV <AVE, ASV <AVE e SQRT AVE> maiores que as correlações entre os construtos com quaisquer outras variáveis) (Fornell \& Larcker, 1981). Os dados obtidos podem ser vistos na Tabela 2.

Tabela 2 - Confiabilidade e Validades Convergente e Discriminate.

\begin{tabular}{lllllllllll}
\hline & CR & AVE & MSV & MaxR(H) & $\mathbf{1}$ & $\mathbf{2}$ & $\mathbf{3}$ & $\mathbf{4}$ & $\mathbf{5}$ & $\mathbf{6}$ \\
\hline 1. Felicidade & 0,775 & 0,683 & 0,338 & 0,795 & $(0,733)$ & & & & & \\
2. Materialismo & 0,706 & 0,613 & 0,154 & 0,745 & $-0,227$ & $(0,620)$ & & & & \\
3. Ansiedade Social & 0,884 & 0,602 & 0,154 & 0,899 & $-0,392$ & 0,310 & $(0,680)$ & & & \\
4. Frugalidade & 0,917 & 0,670 & 0,230 & 0,931 & 0,070 & $-0,215$ & $-0,077$ & $(0,728)$ & & \\
5. Hedonismo & 0,911 & 0,700 & 0,234 & 0,935 & 0,030 & 0,480 & 0,168 & $-0,232$ & $(0,774)$ & \\
6. Conspicuidade & 0,812 & 0,691 & 0,338 & 0,819 & $-0,150$ & 0,581 & 0,267 & $-0,246$ & 0,372 & $(0,768)$
\end{tabular}




\begin{tabular}{lccccccccccc}
\hline & CR & AVE & MSV & MaxR(H) & $\mathbf{1}$ & $\mathbf{2}$ & $\mathbf{3}$ & $\mathbf{4}$ & $\mathbf{5}$ & $\mathbf{6}$ & $\mathbf{7}$ \\
\hline 7. Aceitação Social & 0,876 & 0,643 & 0,061 & 0,882 & $-0,143$ & 0,435 & 0,363 & $-0,227$ & 0,389 & 0,484 & $(0,799)$ \\
\hline
\end{tabular}

Nota: Números entre parênteses representam a raiz quadrada da AVE (SQRT AVE).

Fonte: Elaborado pelos autores.

Usamos o common method bias (CMB) para identificar a variância de todas as variáveis no modelo de medição e obtivemos 0,211. De acordo com Podsakoff et al. (2003) e Siemen et al. (2009), o common method bias (CMB) é uma técnica a ser utilizada com modelos de regressão com interação, sendo que o CMB é indicada sem problema de correlação se menor que 0,5. Por fim, os indicadores apresentados pela análise fatorial confirmatória foram verificados e evidenciaram a validação do modelo. O modelo mostra um ajuste geral com: GFI $=0,904, \mathrm{IFI}=0,923, \mathrm{TLI}=0,913, \mathrm{CFI}=0,922, \mathrm{RMSEA}=0,049, \mathrm{e} \chi^{2}=1039,151, \mathrm{df}=705\left(\chi^{2}\right.$ / df $=1,474 ; \mathrm{p}=0,000)$. Ressalte-se que a razão do qui-quadrado em graus de liberdade está dentro do alcance recomendado de 3 para 1 para os modelos ajustados (Kline, 1998).

\subsection{Teste de Hipóteses}

As análises foram conduzidas por meio de regressão linear múltipla, com a felicidade centrada na média (Y). As variáveis independentes na equação de regressão foram as covariáveis (a) Materialismo (X) e Ansiedade Social (M), e a interação Materialismo e Ansiedade Social (XM) para H1; (b) Frugalidade (X) e Hedonismo (M), e a interação Frugalidade e Hedonismo (XM) para H2; (c) Aceitação Social (X) e Conspicuidade (M), e a interação Aceitação Social e Conspicuidade (XM) para H3, como segue: $Y=a+b 1 X+b 2 M+$ b3XM.

Também adicionamos a técnica de Johnson-Neyman para as três hipóteses a fim de identificar o ponto exato onde o valor de X para o efeito de $\mathrm{M}$ é estatisticamente significante. Portanto, os valores de X em um lado do ponto dos resultados de Johnson-Neyman podem gerar diferenças significantes entre as variáveis (Spiller et al., 2012). Essa técnica fornece uma compreensão específica sobre a medida em como o moderador apresenta resultados no intervalo sobre a qual o efeito é significante. A equação 1 indica o t crítico para $\mathrm{p}<0,001$.

$$
t_{c r i t}=\frac{b_{1}+b_{3} M}{\sqrt{s e_{b 1}^{2}+(2 M) \operatorname{Cov}_{b 1 b 3}+M^{2} s e_{b 3}^{2}}}
$$

Fonte: Hayes (2013, p. 240). 
H1: A ansiedade social amplifica a relação negativa entre felicidade e materialismo.

A nossa primeira hipótese (H1) - a ansiedade social amplifica a relação negativa entre felicidade e materialisno - é ilustrada pela Figura 1, a qual é apresentada no intuito de uma melhor compreensão das relações das variáveis antes da discussão dos resultados.

Figura 1 - H1: Relação entre felicidade, materialismo e ansiedade social

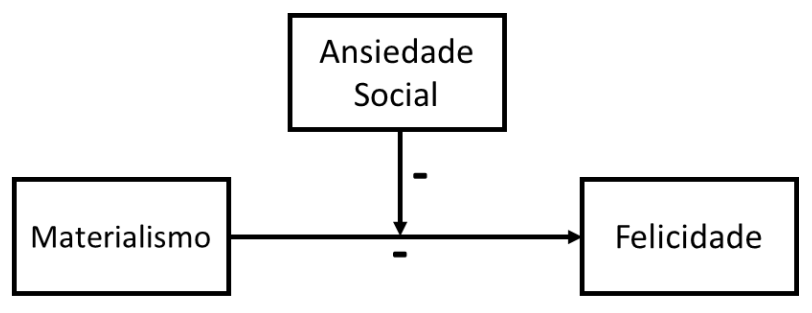

Fonte: Elaborado pelos autores.

Os efeitos da moderação na regressão sobre a felicidade (vide Tabela 3) mostram F (3.193) $=19,8422, \mathrm{p}<0,001, \mathrm{R}^{2}=0,2185$, os efeitos do materialismo $(\beta=-0,1766), \mathrm{t}(193)=-2,5639, \mathrm{p}=$ 0,111 , da ansiedade social $(\beta=-0,1678, \mathrm{t}(193)=-2,2049, \mathrm{p}=0,029)$ e a interação materialismo $\mathrm{x}$ ansiedade social $(\beta=-0,0915, \mathrm{t}(193)=-3,1000, \mathrm{p}=0,022)$. Assim, para cada unidade de materialismo, os participantes obtêm uma redução de 0,1766 unidade na felicidade e para cada unidade de ansiedade social, eles obtêm uma redução de 0,1678 unidade na Felicidade.

Tabela 3 - Modelo de interação entre felicidade, materialismo e ansiedade social

\begin{tabular}{|c|c|c|c|c|}
\hline & & Coef. & Erro Padrão & p \\
\hline \multirow[t]{2}{*}{ Intercepto } & $i_{1}$ & 4,6793 & 0,1007 & $<0,001$ \\
\hline & $b_{1}$ & $-0,1766$ & 0,0689 & 0,111 \\
\hline Materialismo & & 01678 & 0.0761 & 0070 \\
\hline Ansiedade Soci & $b_{3}$ & $-0,0915$ & 0,0295 & 0.022 \\
\hline \multicolumn{5}{|c|}{ Materialismo x Ansiedade } \\
\hline \multicolumn{5}{|c|}{$\mathrm{R}^{2}=0,2185, \mathrm{MSE}=1,2057, \mathrm{~F}(3,193)=19,8422, \mathrm{p}<0.001$} \\
\hline
\end{tabular}

Fonte: Elaborado pelos autores.

Para compreender as inclinações do materialismo que prevê felicidade em cada nível de ansiedade social (vide Figura 2), temos os seguintes resultados: (i) para níveis baixos de ansiedade social, o materialismo tem $\beta=-0,0305, \mathrm{t}(193)=-0,3878, \mathrm{p}=0,6986$ (não significativo) à para baixos níveis de ansiedade social, não há relação entre materialismo e felicidade; (ii) para níveis médios de ansiedade social, o materialismo tem $\beta=-0,1766, \mathrm{t}$ (193) 
$=-2,5639, \mathrm{p}=0,0111$ (significativo) à para níveis médios de ansiedade social, cada unidade de materialismo reduz em 0,1766 o nível de felicidade; e (iii) para altos níveis de ansiedade social, o materialismo tem $\beta=-0,3228, \mathrm{t}(193)=-3,6648, \mathrm{p}=0,0003$ (significativo) à para altos níveis de ansiedade social, cada unidade de materialismo reduz em 0,3228 o nível de felicidade.

A técnica de Johnson-Neyman indica que quando os níveis de ansiedade social são de pelo menos 3,20, o materialismo e a felicidade estão significativamente relacionados, $t(193)=$ $-1,9723, p=0,05, \beta=-0,1352$. À medida que os níveis de Ansiedade Social aumentam, a relação entre Materialismo e Felicidade torna-se mais negativa com os níveis mais elevados de Ansiedade Social (7 vezes maiores), $\beta=-0,4805, \mathrm{t}(193)=-3,7994, \mathrm{p}<0,01$. Os participantes com altos níveis de materialismo e ansiedade social são mais propensos a reduzir sua felicidade com uma inclinação negativa em comparação com os baixos níveis de materialismo. Assim, a Ansiedade Social amplifica a relação negativa entre felicidade e materialismo e os efeitos da interação hipotetizados na H1 são confirmados.

Figura 2 - Hipótese 1: felicidade, materialismo e ansiedade social

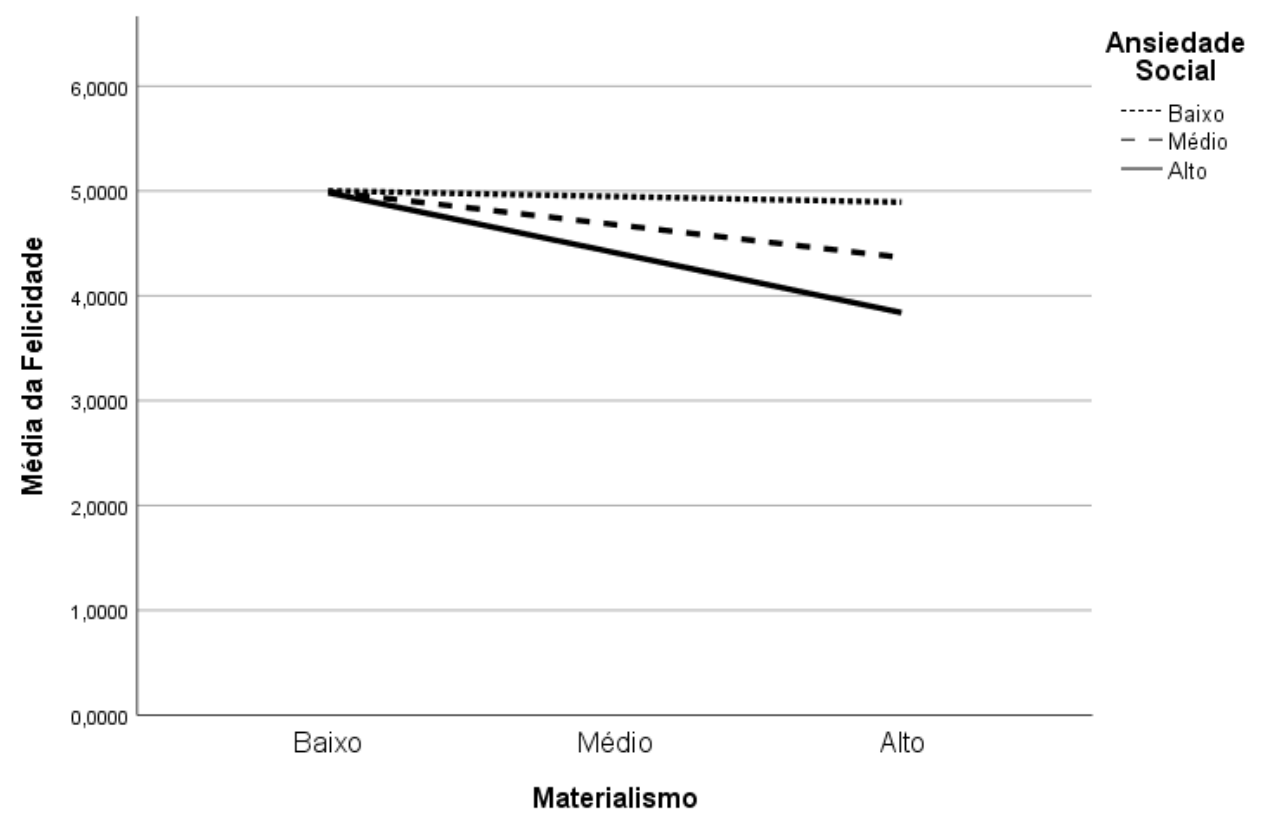

Fonte: Elaborado pelos autores.

H2: O hedonismo modera positivamente a relação positiva entre felicidade e frugalidade.

A Figura 3 representa nossa segunda hipótese (H2) - O hedonismo modera positivamente a relação positiva entre felicidade e frugalidade. A relação nesta figura enfatiza 
a maneira como ambas as variáveis (hedonismo e frugalidade) amplificam níveis positivos de felicidade.

Figura 3 - H2: Relacionamento entre felicidade, hedonismo e frugalidade

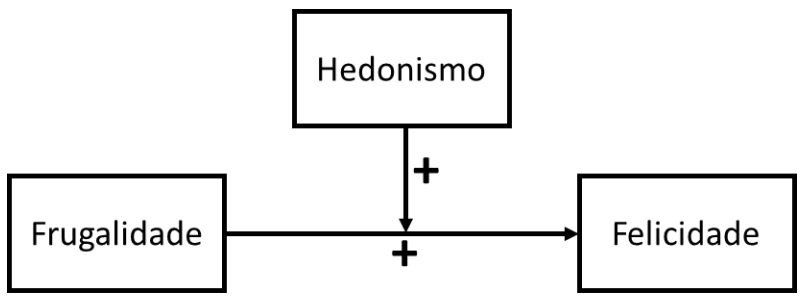

Fonte: Elaborado pelos autores.

Os efeitos da moderação na regressão sobre a felicidade (vide Tabela 4) mostram F $(3,193)=162,1650, \mathrm{p}<0,001, \mathrm{R}^{2}=0,6117$, os efeitos de frugalidade $(\beta=0,4337, \mathrm{t}(193)=$ $13,8381, \mathrm{p}<0,001)$ são significantes, o hedonismo $(\beta=0,4641, \mathrm{t}(193)=11,1564, \mathrm{p}<0,001) \mathrm{e}$ a interação frugalidade $\mathrm{x}$ hedonismo $(\beta=0,0447, \mathrm{t}(193)=2,1457, \mathrm{p}=0,0331)$. Assim, para cada unidade de hedonismo, os participantes obtêm um aumento em 0,4641 unidade na felicidade e para cada unidade de frugalidade, eles obtêm um aumento em 0,4337 unidade na felicidade.

Tabela 4 - Modelo de interação entre felicidade, frugalidade e hedonismo

\begin{tabular}{ccccc}
\hline & & Coef. & Erro Padrão & p \\
\hline Intercepto & $\mathrm{i}_{1}$ & 4,4780 & 0,0552 & $<0,001$ \\
Frugalidade & $\mathrm{b}_{1}$ & 0,4337 & 0,0308 & $<0,001$ \\
Hedonismo & $\mathrm{b}_{2}$ & 0,4641 & 0,0483 & $<0,001$ \\
Frugalidade x Hedonismo & $\mathrm{b}_{3}$ & 0,0447 & 0,0224 & 0,0331 \\
& \multicolumn{2}{l}{$\mathrm{R}^{2}=0,6117, \mathrm{MSE}=0,5990, \mathrm{~F}(3,193)=162,1650, \mathrm{p}<0.001$} & \\
\hline
\end{tabular}

Fonte: Elaborado pelos autores.

Para compreender as inclinações para frugalidade predizendo felicidade em cada nível de hedonismo (vide Figura 4), temos os seguintes resultados: (i) para baixos níveis de hedonismo, a frugalidade tem $\beta=0,3807, \mathrm{t}(193)=12,8601, \mathrm{p}<0,001$ ( significativo) à para níveis baixos de hedonismo, cada unidade de frugalidade aumenta em 0,3807 o nível de felicidade; (ii) para níveis médios de hedonismo, a frugalidade tem $\beta=0,4337, \mathrm{t}$ (193) $=$ 13,8381, p <0,001 (significativo) à para níveis médios de hedonismo, cada unidade de frugalidade aumenta em 0,4337 o nível de felicidade; e (iii) para altos níveis de hedonismo, a 
frugalidade tem $\beta=0,4867, \mathrm{t}(193)=10,1311, \mathrm{p}<0,001$ (significativo) à para altos níveis de hedonismo, cada unidade de frugalidade aumenta em 0,4867 o nível de felicidade. Os participantes com altos níveis de frugalidade e hedonismo apresentam níveis mais elevados de felicidade com uma inclinação positiva em comparação aos baixos níveis de frugalidade e hedonismo. Portanto, o hedonismo modera a relação positiva entre felicidade e frugalidade e os efeitos de interação hipotetizados em H2 são confirmados.

A técnica de Johnson-Neyman indica que não há pontos de transição de significância estatística dentro da faixa observada do moderador. Na verdade, o efeito condicional de X sobre Y é estatisticamente significante em todo o intervalo do efeito moderador (vide inclinações na Figura 4). Em outras palavras, a diferença na frugalidade entre os níveis baixos e altos de hedonismo é significante entre todos os valores de felicidade.

Figura 4 - Hipótese 2: felicidade, frugalidade e hedonismo

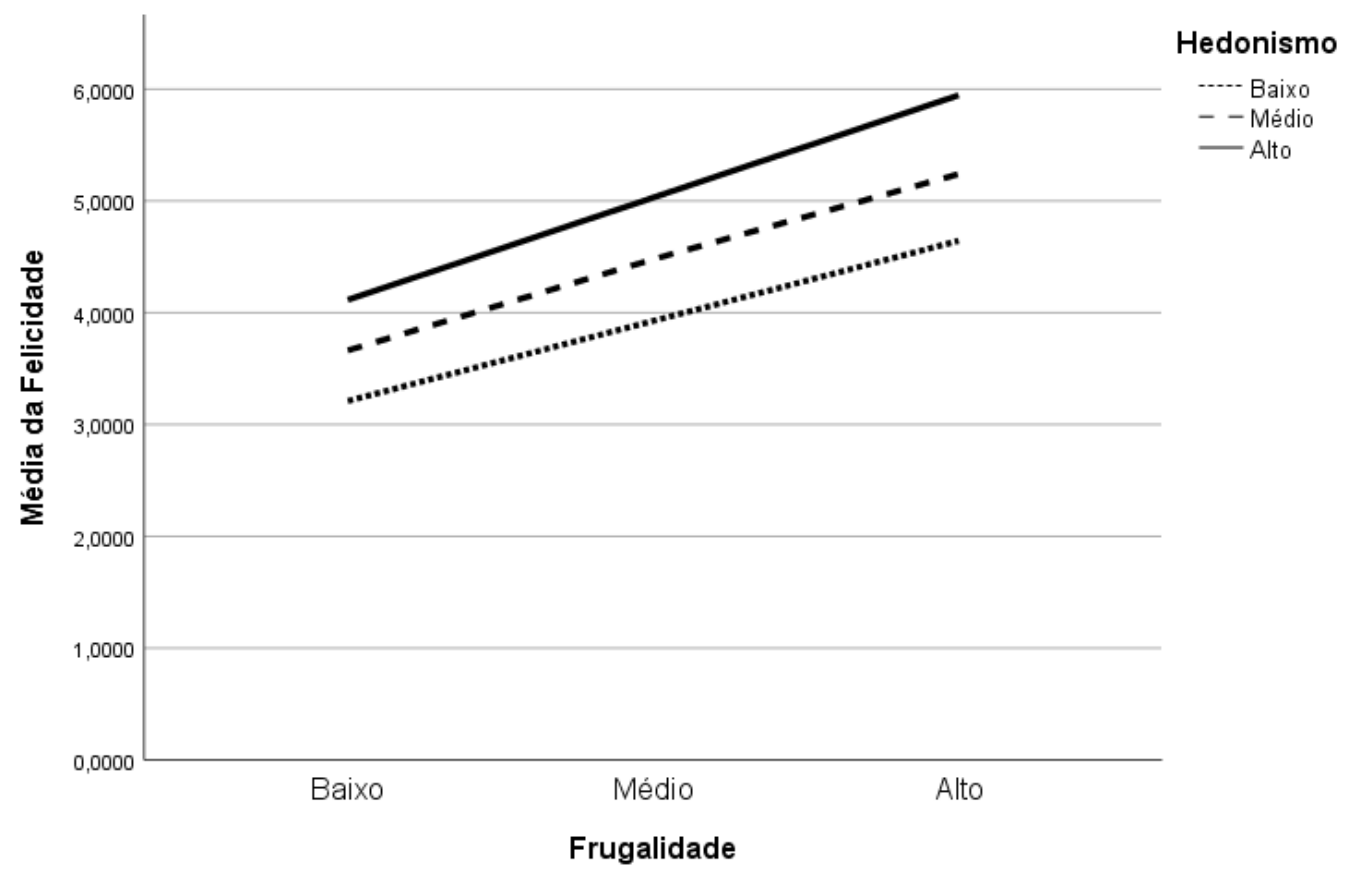

Fonte: Elaborado pelos autores.

H3: Conspicuidade modera negativamente a relação positiva entre Felicidade e Aceitação Social. 
A Figura 5 representa nossa última hipótese (H3) - a conspicuidade modera negativamente a relação positiva entre felicidade e aceitação social. Esta figura destaca uma interação negativa (conspicuidade) entre uma relação positiva (felicidade e aceitação social) de forma que uma reduz a forte relação da outra.

Figura 5 - H3: Relacionamento entre felicidade, conspicuidade e aceitação social

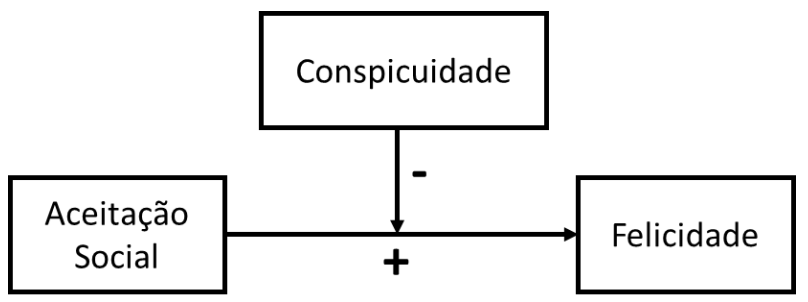

Fonte: Elaborado pelos autores.

Os efeitos da moderação na regressão sobre a felicidade (vide Tabela 5) mostram F significante $(3.193)=19,4094, p<0,001, R^{2}=0,2318$, efeitos de aceitação social $(\beta=0,2452$, $\mathrm{t}(193)=4,0967, \mathrm{p}<0,001$, conspicuidade $(\beta=-0,3001, \mathrm{t}(193)=-4,7741, \mathrm{p}<0,001)$ e a interação conspicuidade $x$ aceitação social $(\beta=-0,0787, \mathrm{t}(193)=-2,0598, \mathrm{p}=0,0408)$. Assim, para cada unidade de aceitação social, os participantes obtêm um aumento de 0,2452 unidade na felicidade e para cada unidade de conspicuidade, obtemos uma redução de -0,3001 unidade na felicidade.

Tabela 5 - Modelo de interação entre felicidade, aceitação social e conspicuidade

\begin{tabular}{ccccc}
\hline & & Coef. & Erro Padrão & p \\
\hline Intercepto & $\mathrm{i}_{1}$ & 4,4828 & 0,0776 & $<0,001$ \\
Aceitação Social & $\mathrm{b}_{2}$ & 0,2452 & 0,0579 & $<0,001$ \\
Conspicuidade & $\mathrm{b}_{1}$ & $-0,3001$ & 0,0546 & $<0,001$ \\
$\begin{array}{c}\text { Conspicuidade x Aceitação } \\
\text { Social }\end{array}$ & $\mathrm{b}_{3}$ & $-0,0787$ & 0,0337 & 0,0408 \\
& & & \\
& $\mathrm{R}^{2}=0,2318, \mathrm{MSE}=1,1852, \mathrm{~F}(3,193)=21,3528, \mathrm{p}<0,001$ & \\
\end{tabular}

Fonte: Elaborado pelos autores.

Para compreender as inclinações para aceitação social que prevê felicidade em cada nível de conspicuidade (vide Figura 6), temos os seguintes resultados: (i) Para níveis baixos de conspicuidade $\beta=0,3583, \mathrm{t}(193)=4,8161, \mathrm{p}<0,001$ (significativo) à para níveis baixos de 
conspicuidade, cada unidade de aceitação social aumenta em 0,3583 o nível de felicidade; (ii) para níveis médios de conspicuidade, aceitação social $\beta=0,2452$, t $(193)=4,2368$, p <0,001 (significativo) à para níveis médios de conspicuidade, cada unidade de aceitação social aumenta em 0,2452 o nível de felicidade; e (iii) para altos níveis de conspicuidade, aceitação social $\beta=$ 0,1320, t (193) $=1,7254, \mathrm{p}=0,0861$ (não significativo) à para alto nível de conspicuidade, não há relação significante entre aceitação social e felicidade.

A técnica de Johnson-Neyman indica que quando os níveis de conspicuidade são, pelo menos, 3,97, a aceitação social e a felicidade ficam significativamente relacionados, $t(193)=$ $1,9723, p=0,05, \beta=0,1443$. À medida que os níveis de conspicuidade diminuem, a relação entre aceitação social e felicidade torna-se mais positiva com os níveis mais baixos de conspicuidade, $\beta=0,3789$, $\mathrm{t}(193)=4,7222, \mathrm{p}<0,001$. Assim, a conspicuidade modera negativamente a relação positiva entre felicidade e aceitação social e os efeitos de interação hipotetizados em H3 são confirmados. Ressalte-se que os participantes com níveis baixos ou médios de conspicuidade tendem a ter a uma relação positiva de aceitação social e felicidade.

Figura 6 - Hipótese 3 - felicidade, aceitação social e conspicuidade



Fonte: Elaborado pelos autores.

\section{Discussão dos resultados}


Partindo da relação entre felicidade, consumo e comportamentos sociais, propomos uma pesquisa com base em três estudos para preencher essa lacuna. Fatores sociais como materialismo, ansiedade social, frugalidade, hedonismo, conspicuidade e aceitação social foram associados à felicidade. Sustentado por essa visão, descobrimos que nossas três hipóteses foram corroboradas pela literatura e nossa investigação fornece contribuições para pesquisas sobre felicidade no consumo.

Para a primeira hipótese, tanto o materialismo quanto a ansiedade social diminuem os níveis de felicidade. Os resultados atuais corroboram estudos anteriores (por exemplo, Costley et al., 2007; Kasser, 2002). Portanto, consumidores materialistas que desejam mais bens e dão ênfase no consumo como uma missão de suas vidas ficam infelizes por não terem tudo o que realmente desejavam. De uma forma negativa, a ansiedade social impacta na felicidade. Se um indivíduo tem medo de ser avaliado/julgado por outros e não se sente confortável em novas situações, podemos atribuir essa situação a uma ansiedade social (Sahranç et al., 2018). Conforme apresentado na Tabela 3 , os coeficientes $b_{1}$ e $b_{2}$ são estatisticamente significantes e influenciam a felicidade em quase a mesma proporção de força.

O presente estudo revelou o efeito moderador da ansiedade social sobre a influência do materialismo na felicidade e fornece várias novas ideias, tanto a nível teórico como prático. Em primeiro lugar, introduzimos o comportamento social ansiedade social para compreender a associação entre materialismo e felicidade. Ao nos concentrarmos especificamente na ansiedade social como moderador, fornecemos uma base mais específica para a compreensão das diferenças sociais na felicidade. Como podemos ver na Figura 2 e na técnica de JohnsonNeyman, apenas para níveis médios e altos de ansiedade social, as inclinações da relação entre materialismo e felicidade são significantes e se amplificaram em uma direção negativa e forte. Indivíduos que pertencem a esse tipo de comportamento devem ser focalizados pelas empresas a fim de elaborar estratégias para que seus clientes utilizem suas marcas a fim de reforçar sua autoestima. Portanto, existe um limiar em não estimular o materialismo.

A segunda hipótese deriva de um lado oposto do materialismo ao relacionarmos a associação de frugalidade e hedonismo com a felicidade. Os consumidores frugais e hedônicos são mais felizes porque gastam dinheiro com sabedoria (Bove et al., 2009, Voss et al., 2003). Os coeficientes de regressão linear múltipla são positivos, como podemos ver na Tabela 4, o que fortalece as relações de frugalidade e hedonismo.

A interação também é positiva em todos os níveis de moderação do papel do hedonismo. Por um lado, as empresas podem garantir que seus clientes tenham o prazer de usar seus 
produtos e marcas; por outro lado, os clientes podem ser mais inteligentes ao comprar apenas o necessário. As estratégias das empresas devem focar em comunicar que suas marcas podem fazer a diferença nas emoções positivas e que adquirir seus produtos e/ou serviços pode valer a pena. Assim, as marcas podem realizar, com seus clientes, o uso de experiências e sentimentos positivos.

A última hipótese investigou a relação entre felicidade, aceitação social e consumo conspícuo. Arslan (2018) concorda que se a pessoa se sente inserida na sociedade e é socialmente valorizada, os níveis de felicidade dessa pessoa tendem a ser mais elevados. Porém, as pessoas desenvolvem algumas táticas para serem socialmente aceitas e uma das formas é adquirir bens/serviços que criem associação ou relacionamento com um ambiente social (Winkelmann, 2012). Os resultados de nossa pesquisa demonstram que quando alguém se força e se sacrifica a comprar algo, isso leva a uma infelicidade geral (Layard, 1980). Assim, se essa ação é apenas para demonstrar uma posição social artificial, por exemplo ser esnobe, ele está sujeito a provocar sentimentos de infelicidade.

O papel moderador da aceitação social da relação entre conspicuidade e felicidade esclarece como alguém pode expressar uma autoimagem ou traços pessoais sob pressões ou normas sociais (Belk, 1988). Nossos resultados indicam que, para níveis baixos e médios de conspicuidade, é estaticamente significante a relação entre aceitação social e felicidade. Isso significa que os consumidores mais conspícuos não se sentem felizes quando a aceitação social é forçada pela aquisição de produtos para pertencer a um grupo social. As empresas podem ser parcimoniosas sobre como a imagem de suas marcas elabora uma distorção difusa da mente do consumidor ou mesmo como a sociedade percebe aquela marca como arrogante. Portanto, as empresas devem construir engajamento com a marca a fim de fornecer laços sociais com seus clientes.

\section{Considerações finais}

A felicidade é considerada um propulsor em nossas vidas e é um assunto complexo devido às diversas áreas de compreensão. Nossa contribuição a essa área visa esclarecer as funções moderadoras dos comportamentos sociais e do consumo na felicidade. Especificamente, examinamos os papéis moderadores de comportamentos sociais (ansiedade social, conspicuidade e aceitação social) e fatores de consumo (hedonismo) na relação entre felicidade e consumo (materialismo e frugalidade). Nossos resultados indicam que a ansiedade social amplifica a relação negativa entre felicidade e materialismo $(\mathrm{H} 1)$, o hedonismo modera 
positivamente a relação positiva entre felicidade e frugalidade $(\mathrm{H} 2)$ e a conspicuidade modera negativamente a relação positiva entre felicidade e aceitação social (H3).

Em primeiro lugar, fornecemos evidências de que a ansiedade social amplifica a relação negativa entre felicidade e materialismo (H1). Dado que as pessoas preocupadas com a percepção dos outros tendem a ser mais materialistas, nossas descobertas sugerem que a preocupação com a avaliação social torna o impacto negativo mais forte do materialismo sobre a felicidade.

Em segundo lugar, fornecemos evidências de que o hedonismo amplifica a relação positiva entre felicidade e frugalidade $(\mathrm{H} 2)$. Tendo em vista que comportamentos frugais levam à paz espiritual e social e, consequentemente, à felicidade, nossos achados sugerem que o hedonismo, relacionado à busca do prazer e redução do estresse (Warburton, 1996), fortalece a relação positiva entre frugalidade e felicidade.

Por fim, fornecemos evidências de que a conspicuidade modera negativamente a relação positiva entre felicidade e aceitação social (H3). Como a aceitação social é definida como a percepção de um indivíduo de ser incluído e valorizado na sociedade e incentivado a fazer parte do ambiente social (Malone et al., 2012), essa percepção pode levar à felicidade. Nossos resultados sugerem que o consumo conspícuo, importante na criação de relacionamentos entre consumidores e marcas, gera status e amplifica a relação positiva entre felicidade e aceitação social, uma vez que quando esses consumidores obtêm, com sucesso, uma impressão desejável por outros em sua volta, há uma obtenção da aprovação social (Xu \& Jin, 2020).

Até onde sabemos, ainda não há estudo sobre os efeitos simultâneos da felicidade no consumo e nos comportamentos sociais (Jaunky et al., 2020). Nosso estudo avança junto à literatura sobre felicidade, esclarecendo essas questões da perspectiva de um país emergente. Nossos resultados implicam empiricamente os níveis de comportamento social do consumidor como um fator-chave na relação entre felicidade e consumo. Essas descobertas não apenas fornecem entendimentos sobre o que fortalece tal relacionamento, mas também proporcionam o ponto de inflexão onde cada uma dessas variáveis reage entre si. Por exemplo, devido aos nossos resultados, as empresas sabem que podem posicionar suas marcas em um mercado premium, mas os consumidores não podem ter a sensação de esnobismo ao usá-las. A razão não se baseia apenas em como os outros os percebem, mas como os consumidores se percebem. Assim, contribuímos para que as empresas idealizem novos movimentos no mercado.

Nossos resultados sugerem que as empresas devem reconhecer os níveis de comportamento social. Especificamente, desde que as empresas possam garantir que os 
consumidores reajam a diferentes níveis desses fatores enquanto consomem marcas, elas também podem, ao mesmo tempo, (i) fazer algum esforço para o engajamento com a marca, (ii) permitir experienciar felicidade e (iii) atrair novos clientes.

Embora tenhamos obtido resultados importantes, é perceptível que o nosso estudo tem limitações. Em pesquisas futuras, uma análise multigrupo poderia ser realizada. Por exemplo, Meisenberg e Woodley (2015) compararam felicidade e satisfação em vários países e para que haja uma comparação intercultural, as análises deveriam fornecer como esses comportamentos sociais diferem em cada caminho da regressão nesses países.

Apesar das questões culturais não serem a ênfase de nosso estudo, também queremos mencionar que felicidade, frugalidade, aceitação social, hedonismo, materialismo, ansiedade social e conspicuidade podem ter significados diferentes em diferentes culturas. Em consonância com isso, é importante entender que o significado de todos esses construtos também pode diferir de cultura para cultura, de idosos para jovens, e também entre indivíduos com altas e baixas rendas. Assim, interpretações parcimoniosas devem ser tomadas ao realizar pesquisas ou experimentos em diferentes culturas, idades e classes sociais.

Por estarmos lidando com comportamentos sociais enquanto os respondentes eram selecionados aleatoriamente para responder ao questionário, poderíamos aplicar um inventário psicométrico a fim de esclarecer o humor dos respondentes. Esses sentimentos ruins podem provocar respostas indesejáveis. Embora tais limitações existissem, este estudo descobriu que os comportamentos sociais revelam a predição de felicidade e em como diferentes níveis de cada fator social interferem em níveis de felicidade, o que acreditamos ter preenchido uma lacuna na literatura.

Estudos futuros devem investigar papéis mediadores e moderadores de outros fatores sociais no contexto da felicidade, como riqueza, orientação ao self e autodependência. Outro estudo intrigante deveria consistir em investigar uma relação de causa-efeito entre comportamentos sociais e intenção de compra mediada pela felicidade. McFerran et al. (2014) afirmam que existe uma relação positiva entre felicidade e intenção de compra. No entanto, essa função de mediação poderia adicionar mais detalhes. Além disso, estudos futuros também devem compreender como esses comportamentos sociais podem causar comportamentos prósociais aos consumidores.

\section{Agradecimentos}


A presente pesquisa é resultado do estudo de pós-doutorado realizado na FGV-EAESP e apoiada financeiramente pela CAPES.

\section{Referências}

American Psychiatric Association (1980). Diagnostic and statistical manual of mental disorders. 3rd ed., Washington, DC: Author.

Anderson, J. C., Gerbing, D. W. (1988). Structural equation modeling in practice: a review and recommended two-step approach. Psychological Bulletin, 103, 411-23.

https://doi.org/10.1037/0033-2909.103.3.411

Arslan, G. (2018). Psychological Maltreatment, Social Acceptance, Social Connectedness, and Subjective Well-Being in Adolescents. Journal of Happiness Studies, 19(4), 983-1001. https://doi:10.1016/j.chiabu.2015.09.010.

Audette, A.P., Lam, S., O'Connor, H. Radcliff, B. (2018). (E)Quality of Life: A CrossNational Analysis of the Effect of Gender Equality on Life Satisfaction. Journal of Happiness Studies. (first online) https://doi.org/10.1007/s10902-018-0042-8.

Babin, B. J., Darden, W. R., Griffin, M. (1994). Work and/or Fun: Measuring Hedonic and Utilitarian Shopping Value. Journal of Consumer Research, 20(4), 644-656. https://doi.org/10.1086/209376

Baumann, Z. (2007). Collateral casualties of consumerism. Journal of Consumer Culture, 7(1), 25-56. https://doi.org/10.1177/1469540507073507

Baumeister, R. F., Leary, M. R. (1995). The need to belong: Desire for interpersonal attachment as a fundamental human motivation. Psychological Bulletin, 117(3), 497-529. https://doi.org/10.1037/0033-2909.117.3.497

Baumeister, R. F., Stillwell, A. M., Heatherton, T. F. (1994). Guilt: An Interpersonal Approach. Psychological Bulletin, 115(2), 243-267. https://doi.org/10.1037/00332909.115.2.243

Bearden, W. O., Netemeyer, R. G., Teel, J. E. (1989). Measurement of Consumer Susceptibility to Interpersonal Influence. Journal of Consumer Research, 15(4), 473-481. https://doi.org/10.1086/209186

Belk, R.W. (1985). Materialism: Trait aspects of living in the material world. Journal of Consumer Research, 12(3), 265-280. https://doi.org/10.1086/208515

Belk, R.W. (1988). Possessions and the Extended Self. Journal of Consumer Research, 15(2), 139-168. https://doi.org/10.1086/209154

Blackhart, G. C., Nelson, B.C., Knowles, M., L. \& Baumeister, R., F. (2009). Rejection elicits emotional reactions but neither causes immediate distress nor lowers self-esteem: a metaanalytic review of 192 studies on social exclusion. Personality and Social Psychology Review, 13(4), 269-309. https://doi.org/10.1177/1088868310368523 
Bögenhold, D., \& Naz, F. (2018). Money, Consumption and Happiness. In Consumption and Life-Styles (pp. 87-102). Palgrave Pivot, Cham.

Bouckaert, L. (2008). Rational versus spiritual concepts of frugality. In L. Bouckaert, H. Opdebeeck and L. Zsolnai (Eds.), Frugality. Rebalancing Material and Spiritual Values in Economic Life, Bern: Peter Lang, pp. 27-43.

Bove, L. L., Nagpal, A., Dorsett, A. D. S. (2009). Exploring the determinants of the frugal shopper. Journal of Retailing and Consumer Services, 16(4), 291-297.

https://doi.org/10.1016/j.jretconser.2009.02.004

Burroughs, J. E., Rindfleisch, A. (2002). Materialism and well-being: A conflicting values perspective. Journal of Consumer Research, 29(3), 348-370. https://doi.org/10.1086/344429

Buss, A. H. (1980). Self-consciousness and social anxiety. New York: W. H. Freeman.

Campbell, C. (1987). The Romantic Ethic and the Spirit of Modern Consumerism, Basil Blackwell, Oxford.

Chitturi, R., Raghunathan, R., Mahajan, V. (2007). Form versus function: How the intensities of specific emotions evoked in functional versus hedonic trade-offs mediate product preferences. Journal of Marketing Research, 44(4), 702-714.

https://doi.org/10.1509/jmkr.44.4.702

Corral-Verdugo, V., Mireles-Acosta, J., Tapia-Fonllem, C., Fraijo-Sing, B. (2011). Happiness as correlate of sustainable behavior: a study of pro-ecological, frugal, equitable and altruistic actions that promote subjective well-being. Research in Human Ecology, 18(2), 95-104.

Costley, C. Friend, L., Messe, E., Ebbers, C., Wang, L.-J. (2007). Happiness, Consumption, and Being. In: Belk, R. and Sherry Jr., J. F. (Ed.), Consumer Culture Theory. Research in Consumer Behavior, Volume 11 (pp. 209-240), Oxford, UK, Elsevier.

DeYoung, R. (1986). Encouraging environmentally appropriate behavior: The role of intrinsic motivation. Journal of Environmental Systems, 15(4), 281-291. https://10.2190/3FWV4WM0-R6MC-2URB

Diener, E., Seligman, M. E. (2002). Very happy people. Psychological Science, 13(1), 81-84. https://doi.org/10.1111/1467-9280.00415

Dillon, W. R., Madden, T. J., Firtle, N. H. (1993). Research in a marketing environment. St. Louis: Times Mirror.

Dittmar, H., Pepper, L. (1994). To have is to be: Materialism and person perception in working-class and middle-class British adolescents. Journal of Economic Psychology, 15(2), 233-251. https://doi.org/10.1016/0167-4870(94)90002-7

Easterlin R. (1974). Does Economic Growth Improve the Human Lot? In: David, P.A. and Reder, M.W. (Ed.), Nations and Households in Economic Growth: Essays in Honor of Moses Abramovitz (pp. 89-125), New York, Academic Press. 
Erdfelder, E., Faul, F., Buchner, A. (1996). Behavior Research Methods, Instruments, \& Computers, 28(1), 1-11. https://doi.org/10.3758/BF03203473

Flurry, L. A., Swimberghe, K., \& Allen, J. (2021). Exposing the moderating impact of parentchild value congruence on the relationship between adolescents' materialism and subjective well-being. Journal of Business Research, 128, 290-302.

https://doi.org/10.1016/j.jbusres.2021.02.005

Fornell, C., Larcker, D.F. (1981). Evaluating structural equation models with unobservable variables and measurement error, Journal of Marketing Research, 18(1), 39-50.

https://doi.org/10.2307/3151312

Frank, R. H. (2008). Should public policy respond to positional externalities?. Journal of Public Economics, 92(8-9), 1777-1786. https://doi.org/10.1016/j.jpubeco.2008.03.001

Goldsmith, R. E., Clark, R. A. (2012). Materialism, status consumption, and consumer independence. Journal of Social Psychology, 152(1), 43-60.

https://10.1080/00224545.2011.555434

Goldsmith, R. E., Flynn, L. R., Clark, R. A. (2011). Materialism and brand engagement as shopping motivations. Journal of Retailing and Consumer Services, 18(4), 278-284. https://doi.org/10.1016/j.jretconser.2011.02.001

Gui, B., \& Stanca, L. (2010). Happiness and relational goods: well-being and interpersonal relations in the economic sphere. International Review of Economics, 57(2), 105-118. https://doi.org/10.1007/s12232-010-0099-0

Hayes, A. F. (2012). PROCESS: A versatile computational tool for observed variable mediation, moderation, and conditional process modeling [White paper]. Retrieved from http://www.afhayes.com/public/process2012.pdf

Hayes, A. F. (2013). Introduction to Mediation, Moderation, and Conditional Process Analysis: A Regression-Based Approach. New York, NY: The Guilford Press.

Hayes, A. F., Matthes, J. (2009). Computational procedures for probing interactions in OLS and logistic regression: SPSS and SAS implementations. Behavior Research Methods, 41, 924-936. https://10.3758/BRM.41.3.924

Hirschman, E. C., Holbrook, M. B. (1982). Hedonic Consumption: Emerging Concepts, Methods and Propositions. Journal of Marketing, 46(3), 92-101.

https://doi.org/10.2307/1251707

Hu, M., Xiang, G., \& Zhong, S. (2021). The Burden of Social Connectedness: Do Escalating Gift Expenditures Make You Happy?. Journal of Happiness Studies, 1-19. https://doi.org/10.1007/s10902-020-00341-6

Huneke, M. E. (2005). The Face of the Un-Consumer: An Empirical Examination of the Practice of Voluntary Simplicity in the United States. Psychology \& Marketing, 22(7), 527550. https://doi.org/10.1002/mar.20072 
Iyer R, Muncy J. (2009). Purpose and object of anticonsumption. Journal of Business Research, 62(2), 160-168. https://doi.org/10.1016/j.jbusres.2008.01.023

Jaikumar, S., Singh, R., \& Sarin, A. (2018). 'I show off, so I am well off': Subjective economic well-being and conspicuous consumption in an emerging economy. Journal of Business Research, 86, 386-393. https://doi.org/10.1016/j.jbusres.2017.05.027

Jaunky, V.C., Jeetoo, J., Rampersad, S. (2020). Happiness and Consumption in Mauritius: An Exploratory Study of Socio-Economic Dimensions, Basic Needs, Luxuries and Personality Traits. Journal of Happiness Studies, 21(7), 2377-2403. https://doi.org/10.1007/s10902-01900178-8

Johnson, P. O., Fay, L. C. (1950). The Johnson-Neyman Technique, Its Theory and Application. Psychometrika, 15(4), 349-367. https://doi.org/10.1007/BF02288864

Kasser, T. (2002). The high price of materialism. Cambridge, MA: MIT Press.

Kaus, W. (2013). Conspicuous consumption and "race": Evidence from South Africa. Journal of Development Economics, 100(1), 63-73. https://doi.org/10.1016/j.jdeveco.2012.07.004

Kline, R. B. (1998), Principles and Practice of Structural Equation Modeling, Guilford Press, New York, NY.

Lastovicka, J. L., Bettencourt, L. A., Hughner, R. S., Kuntze, R. J. (1999). Lifestyle of the tight and frugal: Theory and measurement. Journal of Consumer Research, 26(1), 85-98.

Layard, R. (1980). Human Satisfactions and Public Policy. Economic Journal, 90(360), $737-$ 750. https://doi.org/10.1086/209552

Lee, M. S. W., Ahn, C. S. Y. (2016). Anti-consumption, Materialism, and Consumer Wellbeing. Journal of Consumer Affairs, 50(1), 18-47. https://doi.org/10.1111/joca.12089

Leigh, J. H., Gabel, T. G. (1992). Symbolic Interactionism: Its Effects on Consumer Behaviour and Implications for Marketing Strategy. Journal of Services Marketing, 6(3), 516. https://doi.org/10.1108/EUM0000000002594

Loureiro, S. M. C. (2017). Consumption and Well-Being: Collecting Experiences Rather Than Material Possessions. In: Li, E. Y. Advances in Marketing Customer Relationship Management, and e-Services Book Series. Hershey, PA: IGI Global.

Lyubomirsky, S., Lepper, H. S. (1999). A Measure of Subjective Happiness: preliminary reliability and construct validation. Social Indicators Research, 46(2), 137-155. https://doi.org/10.1023/A:1006824100041

Malone, G. P., Pillow, D. R., Osman, A. (2012). The general belongingness scale (GBS): Assessing achieved belongingness. Personality and Individual Differences, 52(3), 311-316. https://doi.org/10.1016/j.paid.2011.10.027

Mattick, R., Clarke, C. (1998). Development and Validation of Measure of Social Phobia Scrutiny Fear and Social Interaction Anxiety. Behavior Research and Therapy, 36(4), 455- 
470. https://doi.org/10.1016/S0005-7967(97)10031-6

McFerran, B., Aquino, K., Tracy, J. L. (2014). Evidence for Two Facets of Pride in Consumption: Findings from Luxury Brands. Journal of Consumer Psychology, 24(4), 455471. https://doi.org/10.1016/j.jcps.2014.03.004

Mead, N., Baumeister, R., Stillman, T., Rawn, C. (2010). Social Exclusion Causes People to Spend and Consume Strategically in the Service of Affiliation. Journal of Consumer Research, 37(5), 902-919. https://doi.org/10.1086/656667

Meisenberg, G., Woodley, M. A. (2015). Gender Differences in Subjective Well-Being and Their Relationships with Gender Equality. Journal of Happiness Studies, 16(6), 1539-1555. https://doi.org/10.1007/s10902-014-9577-5

Myers, D. (2000). The funds, friends, and faith of happy people. American Psychologist, 55(1), 56-67. https://doi.org/10.1037/0003-066X.55.1.56

Norris, J. I., Larsen, J. T. (2011). Wanting more than you have and its Consequences for Well-being. Journal of Happiness Studies, 12(5), 877-885. https://doi.org/10.1007/s10902010-9232-8

O'Cass, A., McEwen, H. (2004). Exploring consumer status and conspicuous consumption. Journal of Consumer Behaviour, 4(1), 25-39. https://doi.org/10.1002/cb.155

O'Shaughnessy, J., O'Shaughnessy, N. J. (2002). Marketing, the consumer society and hedonism. European Journal of Marketing, 36(5), 524-547.

https://doi.org/10.1108/03090560210422871

Pan, L., Pezzuti. T., Lu, W., Pechmann, C. (2019). Hyperopia and frugality: Different motivational drivers and yet similar effects on consumer spending, Journal of Business Research, 95, 347-356. https://doi.org/10.1016/j.jbusres.2018.08.011

Podsakoff, P.M., Mackenzie, S.B., Lee, J.Y.; Podsakoff, N.P. (2003). Common method biases in behavioral research: A critical review of the literature and recommended remedies. Journal of Applied Psychology, 88(5), 879- 903. https://doi.org/10.1037/0021-9010.88.5.879

Richins, M. L. (2004). The Material Values Scale: Measurement Properties and Development of a Short Form. Journal of Consumer Research, 31(1), 209-219.

https://doi.org/10.1086/383436

Richins, M. L., Dawson, S. (1992). A Consumer Values Orientation for Materialism and its Measurement: Scale Development and Validation, Journal of Consumer Research, 19(3), 303-316. https://doi.org/10.1086/209304

Sahranç, Ü., Çelik, E., Turan, M. E. (2018). Mediating and Moderating Effects of Social Support in the Relationship Between Social Anxiety and Hope Levels in Children. Journal of Happiness Studies, 19(4), 1003-1019. https://10.1007/s10902-017-9855-0

Schroeder, J. E., Dugal, S. S. (1995). Psychological Correlates of the Materialist Construct. Journal of Social Behavior and Personality, 10(1), 243-253. 
Sharma, P. (2010). Country of origin effects in developed and emerging markets: exploring the contrasting roles of materialism and value consciousness. Journal of International Business Studies, 42(2), 1-22. https://doi.org/10.1057/jibs.2010.16

Shaw, J. W. (2002). Materialism, Psychological Well-Being, and Overall Quality of Life. Quality of Life Research, 11 (7), 661. https://doi.org/10.1023/A:1006820429653

Sheth, J.N., Newman, B.I., Gross, B.L. (1991). Consumption Values and Market Choices: Theory and Applications, South-Western Publishing, Cincinnati, OH.

Shukla, P. (2011). Impact of interpersonal influences, brand origin and brand image on luxury purchase intentions: measuring interfunctional interactions and a cross-national comparison. Journal of World Business, 46(2), 242-52. https://doi.org/10.1016/j.jwb.2010.11.002

Shukla, P. (2012). The influence of value perceptions on luxury purchase intentions in developed and emerging markets. International Marketing Review, 29(6), 574-596. https://doi.org/10.1108/02651331211277955

Siemsen, E., Roth, A., Oliveira, P. (2010). Common Method Bias in Regression Models with Linear, Quadratic, and Interaction Effects. Organizational Research Methods, 13(3), 456-476. https://doi.org/10.1177/1094428109351241

Sirgy, M. J., Lee, D.-J., Rahtz, D. (2007). Research on Consumer Well-Being (CWB): Overview of the Field and Introduction to the Special Issue. Journal of Macromarketing, 27(4), 341-349. https://doi.org/10.1177/0276146707307212

Sjåstad, H., Zhang, M., Masvie, A. E., \& Baumeister, R. (2021). Social exclusion reduces happiness by creating expectations of future rejection. Self and Identity, 20(1), 116-125. https://doi.org/10.1080/15298868.2020.1779119

Spiller, S. A., Fitzsimons, G. J., Lynch, J. G., McClelland, G. (2012). Spotlights, Floodlights, and the Magic Number Zero: Simple Effects Tests in Moderated Regression. Journal of Marketing Research, 50(2), 277-288. https://doi.org/10.1509/jmr.12.0420

Stevenson, B., Wolfers, J. (2008). Economic growth and Happiness: Reassessing the Easterlin Paradox. NBER Working papers 14282, National Bureau of Economic Research, Inc.

Retrieved from http://ftp.iza.org/dp3654.pdf

Sullivan, L., Harnish, R. (1990). Body image: Differences in high and low self-monitoring males and females'. Journal of Research in Personality, 24(3), 291-302.

https://doi.org/10.1016/0092-6566(90)90022-X

Tabachnick, B. G., L. S. Fidell (2001). Using Multivariate Statistics, 4th Edition, Allyn and Bacon, Needham Heights, MA.

Tanzer, J.R., Weyandt, L. (2020). Imaging Happiness: Meta Analysis and Review. Journal of Happiness Studies, 21(7), 2693-2734. https://doi.org/10.1007/s10902-019-00195-7 
Trigg, A. (2001). Veblen, Bourdieu, and conspicuous consumption. Journal of Economic Issues, 35(1), 99-115. https://doi.org/10.1080/00213624.2001.11506342

Veenhoven, R. (2003). Hedonism and Happiness. Journal of Happiness Studies, 4(4), 437457. https://doi.org/10.1023/B:JOHS.0000005719.56211.fd

Venkatesh, A. (1994). India's Changing Consumer Economy: A Cultural Perspective. Advances in Consumer Research, 21, 323-328.

Vigneron, F., Johnson, L.W. (2004). Measuring perceptions of brand luxury. Journal of Brand Management, 11(6), 484-508. https://doi.org/10.1057/palgrave.bm.2540194

Voss, K. E., Spangenberg, E. R., Grohmann, B. (2003). Measuring the Hedonic and Utilitarian Dimensions of Consumer Attitude. Journal of Marketing Research, 25(3), 310320. https://doi.org/10.1509/jmkr.40.3.310.19238

Waldinger, R. J., Schulz, M. S. (2010). What's Love Got To Do With It?: Social Functioning, Perceived Health, and Daily Happiness in Married Octogenarians. Psychology Aging, 25(2), 422-431. https://10.1037/a0019087

Wang, H., Cheng, Z., \& Smyth, R. (2019). Consumption and happiness. The Journal of Development Studies, 55(1), 120-136. https://doi.org/10.1080/00220388.2017.1371294

Wang, L., Gu, D., Jiang J., Sun, Y. (2019). The Not-So-Dark Side of Materialism: Can Public Versus Private Contexts Make Materialists Less Eco-Unfriendly?, Frontiers in Psychology, 10:790, 1-10. https://10.3389/fpsyg.2019.00790

Wang, R., Liu, H., Jiang, J., Song, Y. (2017). Will materialism lead to happiness? A longitudinal analysis of the mediating role of psychological needs satisfaction. Personality and Individual Differences, 105, 312-317. https://doi.org/10.1016/j.paid.2016.10.014

Warburton, D. M. (1996). The functions of pleasure: In D. M. Warburton and N. Sherwood (eds), Pleasure and Quality of life, Wiley: Chichester.

Warde, A. (1994). Consumption, identity-formation and uncertainty. Sociology, 28(4), 877898. https://doi.org/10.1177/0038038594028004005

Winkelmann, R. (2012). Conspicuous consumption and satisfaction. Journal of Economic Psychology, 33(1), 183-191. https://doi.org/10.1016/j.joep.2011.08.013

Wong, N., Ahuvia, A. (1998). Personal taste and family face: Luxury consumption in Confucian and Western societies. Journal of Psychology and Marketing, 15(5), 423-441. https://doi.org/10.1002/(SICI)1520-6793(199808)15:5<423::AID-MAR2>3.0.CO;2-9

Xu, W., Jin, X. (2020). How social exclusion and temporal distance influence product choices: the role of coping strategies. Asia Pacific Journal of Marketing and Logistics, 33(2), 351-370. https://doi.org/10.1108/APJML-05-2019-0338 


\section{Apêndice A - Escalas em inglês e português}

\section{Felicidade Subjetiva}

Lyubomirsky and Lepper (1999)

1. In general, I consider myself

not a very person a very happy person

2. Compared to most of my peers, I consider myself

less happy more happy

3. Some people are generally very happy. They enjoy life regardless of what is going on, getting the most out of everything. To what extent does this characterization describe you? not at all a great deal

4. Some people are generally not very happy. Although they are not depressed, they never seem as happy as they might be. To what extent does this characterization describe you?

not at all a great deal

Português

1. De modo geral, eu me considero...

uma pessoa não muito feliz uma pessoa feliz

2. Comparado com a maioria das pessoas que conheço, eu me considero...

menos feliz mais feliz

3. Normalmente, algumas pessoas são felizes. Elas curtem a vida independentemente do que esteja acontecendo, aproveitando o máximo de tudo. De que forma essa frase caracteriza você?

De forma alguma Exatamente assim

4. Normalmente, algumas pessoas não são tão felizes. Embora elas não sejam depressivas, elas nunca parecem tão alegres quanto elas devem ser. De que forma essa frase caracteriza você?

De forma alguma Exatamente assim

\section{Ansiedade Social}

Mattick and Clarke (1998)

1. I get nervous if I have to speak with someone in authority (teacher, boss, etc.)

2. I have difficulty making eye-contact with others

3. I become tense if I have to talk about myself or my feelings

4. I find difficulty mixing comfortably with the people I work with

5. I tense-up if I meet an acquaintance in the street

6. When mixing socially I am uncomfortable

7. I feel tense if I am alone with just one other person

8. I am at ease meeting people at parties, etc.

9. I have difficulty talking with other people

10. I find it easy to think of things to talk about.

11. I worry about expressing myself in case I appear awkward

12. I find it difficult to disagree with another's point of view

13. I have difficulty talking to attractive persons of the opposite sex

14. I find myself worrying that I won't know what to say in social situations 
15. I am nervous mixing with people I don't know well

16. I feel I'll say something embarrassing when talking

17. When mixing in a group I find myself worrying I will be ignored

18. I am tense mixing in a group

19. I am unsure whether to greet someone I know only slightly

Português

1. Fico nervoso em ter que falar com alguma pessoa em um nível mais alto que o meu (chefe no trabalho etc.)

2. Tenho dificuldade em manter contato olho no olho com outras pessoas

3. Fico tenso quando tenho que falar sobre mim ou meus sentimentos

4. Tenho dificuldade em me relacionar com as pessoas com quem trabalho.

5. Fico tenso quando me encontro com um conhecido na rua

6. Quando estou em grupos sociais eu não me sinto desconfortável

7. Sinto-me tenso quando estou sozinho com uma única pessoa em um ambiente

8. Tenho facilidade em falar com pessoas em festas, encontros etc.

9. Tenho dificuldade em falar com outras pessoas

10. Acho fácil pensar em coisas para iniciar uma conversa

11. Preocupo-me em parecer esquisito/estranho quando estou falando sobre mim

12. Tenho dificuldade em discordar com o ponto de vista de outras pessoas

13. Tenho dificuldade em falar com pessoas atraentes do sexo oposto

14. Fico me preocupando em não saber o que dizer em eventos sociais

15. Fico nervoso quando me socializo com pessoas que não conheço muito bem

16. Sinto que digo algo sem sentido quando falo

17. Preocupo-me em ser ignorado quando estou me socializando

18. Fico tenso quando me socializo

19. Sinto-me desconfortável em cumprimentar alguém que não conheço muito bem.

\section{Materialismo}

Richins (2004)

1. It is important to me to have really nice things.

2. I would like to be rich enough to buy anything I want.

3. I would be happier if I could afford to buy more things.

4. It sometimes bothers me quite a bit that I cannot afford to buy all the things I want.

5. People place too much emphasis on material things.

6. It's really true that money can buy happiness.

Português

1. É importante para mim que possa ter coisas de bom gosto.

2. Gostaria de ser rico suficiente para comprar tudo que gostaria de ter.

3. Seria mais feliz se pudesse comprar mais coisas

4. Às vezes fico aborrecido quando não consigo comprar tudo que quero

5. As pessoas colocam muito foco em coisas materiais

6. É verdade que o dinheiro pode comprar felicidade

\section{Frugalidade}

Lastovicka et al. (1999) 
1. If you take good care of your possessions, you will definitely save money in the long run

2. There are many things that are normally thrown away that are still quite useful

3. Making better use of my resources makes me feel good

4. If you can re-use an item you already have, there's no sense in buying something new

5. I believe in being careful in how I spend my money

6. I discipline myself to get the most from my money

7. I am willing to wait on a purchase I want so that I can save money

8. There are things I resist buying today so I can save for tomorrow

Português

1. Se você cuida bem de seus bens, com certeza você economizará dinheiro no longo prazo

2. Há muitas coisas que normalmente são jogadas fora, mas que ainda podem ser usadas

3. Fazer um melhor uso de meus bens me faz sentir bem

4. Se você pode reutilizar algo que você já possui, não faz sentido comprar algo novo

5. Sou cauteloso em como eu gasto meu dinheiro.

6. Eu me disciplino para tirar o máximo de proveito do meu dinheiro

7. Estou disposto a esperar comprar algo que quero para que possa economizar dinheiro

8. Há coisas que resisto a comprar hoje para que eu possa economizar para amanhã

\section{Hedonismo}

Babin, Darden and Griffin (1994)

1. This shopping trip was truly a joy.

2. Compared to other things I could have done, the time spent shopping was truly enjoyable.

3. I continued shopping, not because I had to, but because I wanted to.

4. This shopping trip truly felt like a scape.

5. I enjoyed being immersed in exciting new products.

6. I enjoyed this shopping trip for its own sake, not just for items I may have purchased.

7. I continue to shop not because I had to, but because I wanted to.

8. I had a good time because I was able to act on the "spur of moment".

9. While shopping, I was able to forget my problems

10. While shopping, I felt a sense of adventure

11. I was able to do a lot of fantazing during this trip

Português

12- Eu me divirto ao fazer compras

13- Comparando com outras coisas que eu poderia fazer, o tempo gasto comprando é muito mais agradável

14- Eu faço compras porque quero e não por obrigação

15- Fazer as compras é uma forma de fuga/sair da rotina.

16- Gosto de participar de forma intensa na escolha e compra de novos produtos

17- Gosto de fazer compras só pelo fato de pensar em sair e não pelos produtos que compro

18- Faço compras não porque eu tenho que fazer, eu faço compras porque gosto.

19- Sair para comprar é uma forma de me motivar positivamente

20- Esqueço os meus problemas enquanto estou comprando

21- Quando saio para comprar sinto uma sensação de aventura

22- Fazer compras é uma forma de imaginar/fantasiar na vida.

\section{Aceitação Social (Normativa)}

Bearden, Netemeyer and Teel (1989) 
1. I rarely purchase the latest fashion styles until I am sure my friends approve of them.

2. It is important that others like the products and brands I buy.

3. When buying products, I generally purchase those brands that I think others will approve of.

4. If other people can see me using a product, I often purchase the brand they expect me to buy.

5. I like to know what brands and products make good impressions on others.

6. I achieve a sense of belonging by purchasing the same products and brands that others purchase. If I want to be like someone, I often try to buy the same brands that they buy. 7. I often identify with other people by purchasing the same products and brands they purchase.

Português

1. Eu raramente compro os estilos mais recentes de moda até ter certeza de que meus amigos os aprovam.

2. É importante que outras pessoas gostem dos produtos e marcas que compro.

3. Ao comprar produtos, geralmente compro marcas que eu acho que outros vão aprovar.

4. Se outras pessoas podem me ver usando um produto, eu costumo comprar as marcas que eles esperam que eu compre.

5. Gosto de saber quais marcas e produtos causam boas impressões sobre as outras pessoas.

6. Tenho um sentimento de pertencimento social quando compro os mesmos produtos e marcas que outros compram. Se eu quiser ser como alguém, muitas vezes tento comprar as mesmas marcas que compram.

7. Muitas vezes eu me identifico com outras pessoas comprando os mesmos produtos e marcas que elas compram.

\section{Conspicuidade}

Shukla (2012)

\section{Valores Conspícuos}

1. Owning luxury goods indicates a symbol of achievement

2. Owning luxury goods indicates a symbol of wealth

3. Owning luxury goods indicates a symbol of prestige

4. Owning luxury goods attracts attention

Português

1. Ter bens de luxo indica sucesso

2. Ter bens de luxo simboliza riqueza

3. Ter bens de luxo simboliza prestígio

4. Ter bens de luxo atrai atenção de outras pessoas 